Universidad Nacional de La Plata

Facultad de Humanidades y Ciencias de la Educación

Maestría en Educación Corporal

Tesis para optar al grado de Magíster en Educación Corporal:

\title{
La administración del cuerpo infantil en el SXVIII: una lectura sobre el inicio de la ortopedia infantil
}

Alumna: Daniela Yutzis

E-mail: danielayutzis@ciudad.com.ar

Director de Tesis: Dr. Edgardo Castro

La Plata, octubre 2008. 


\section{Índice}

3. L'orthopédie ou l'art de prévenir et corriger dans les enfans les

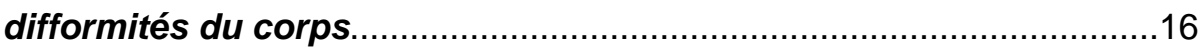

3.1. Las fuentes. 18

3.1.a. La Pédotrophie 19

3.1.b. La Callipédie .20

3.2. El texto 22

4. La medicina. 31

5. Nodrizas, pechos y amamante 41

6. Infancia y familia. 49

6. 1. Infancia 49

6. 2. Familia y policía. .54

7. Cuerpos bellos. 59

8. Conclusiones

9. Bibliografía 84

10. Índice de ilustraciones .87 


\section{La administración del cuerpo infantil en el SXVIII: una lectura sobre el inicio de la ortopedia infantil}

\section{Introducción}

El presente trabajo propone una lectura crítica de L'orthopédie ou l'art de prévenir et corriger dans les enfans, les difformités du corps ${ }^{1}$ de N. Andry, con el objeto de pensar la particularidad del cuerpo infantil en el siglo XVIII a la luz de la aparición del primer libro que nombra a la ortopedia.

La elección de abordar el trabajo a partir de la lectura de una fuente primaria tuvo como objetivo partir de un inventario del texto que permitiera poner de relieve un sistema de pensamiento mediante el análisis de aquellos fragmentos de discursos que conllevan en sí mismos parte de una realidad de la que de algún modo fueron protagonistas. Significa rastrear en un texto los trazos o esbozos que den cuenta de la administración del cuerpo en un acontecimiento; retomar palabras, gestos, discursos que han decidido -y en parte deciden hoy también- sobre la conformación del cuerpo infantil en tanto discursos y formas que atravesaron la vida misma del cuerpo.

Siguiendo la propuesta de Foucault de describir con una mirada vertical aquello que hay de común en los distintos saberes de una época, nuestra intención es tomar determinados detalles que han sido significativos en la administración del cuerpo infantil en el siglo XVIII y explorar aquellas obviedades o elementos en apariencia mínimos que se encuentran más ligados a determinadas contingencias pasajeras más allá de su complejidad- que a constantes de procesos continuos sumergidos en una línea única de progreso. En este sentido, este abordaje se puede considerar histórico en la medida en que está centrado en un estudio histórico de la constitución de ciertas prácticas de la pedagogía y constitución del cuerpo infantil.

\footnotetext{
${ }^{1}$ La ortopedia o el arte de prevenir y de corregir en los niños las deformidades del cuerpo, editada en Bélgica en 1743. Si bien Andry reside en Francia, el impresor y librero George Fricxs reside en Bruselas trabajando en relación con la Imprenta Real. El texto está impreso en un papel que lleva una filigrana en forma de racimo de uvas firmado por L. Larroche, que atestigua la casa de la edición.
} 
Inmerso en un terreno absolutamente universal, el de la formación del cuerpo del niño, nuestro abordaje implica a su vez un elemento acotado, esto es que tiene una particularidad nacional y cultural, un momento, un espacio y un tiempo: la presentación del texto en el año 1743, Francia en el siglo XVIII.

A su vez, esta tesis se encuadra en el estudio de la familia burguesa de la época, allí donde en primera instancia se problematiza la sexualidad infantil, se medicaliza la sexualidad de la mujer y se alerta sobre la urgencia de observar y controlar a los niños para evitar trastornos patológicos. Hay una autoexaltación de la clase burguesa que se preocupa y encarga de su procreación y descendencia, que en una segunda instancia se extenderá hacia el resto de la población como medio de control económico y sujeción política (Foucault; 2002; 149). Una clase que hizo valer su cuerpo, la salud, su sexualidad y la organización de sus placeres en el plano de la construcción política de la vida. Un cuerpo digno de ser diferenciado, cuidado y separado para ser preservado de contactos con el mundo exterior que puedan implicar peligro.

Nuestra investigación sobre el inicio de la ortopedia infantil no se ciñe al desarrollo puramente científico y anatómico, ni se centra con exclusividad en la historia de los discursos y mentalidades; pretende, en cambio, ser una historia de la corrección del cuerpo que permita indagar en cómo los dispositivos de poder se articularon directamente sobre el cuerpo, allí donde lo histórico y lo biológico se ligan conforme al desarrollo de las tecnologías de poder que se centran en la vida misma: es el modo en que se invadió lo más material y viviente de la vida misma (Foucault; 2002; 184).

Es nuestra intención puntualizar lo particular de la corrección de la postura del cuerpo infantil en relación a ciertas tecnologías de poder, en un corte sagital que presente en situaciones de experiencias los hechos que de algún modo acompañan su propia actualidad: la nueva organización del espacio y control familiar que toma a su cargo el cuerpo y la vida del niño; la medicina en su intervención sobre la vida misma; la situación de las nodrizas en relación a la crianza; la solicitud a las madres para que amamanten a sus hijos, la aparente liberación del uso de las fajas en los niños; el pedido a los padres para que vigilen a sus niños. 
Una historia de la ortopedia infantil en tanto experiencia ${ }^{2}$ que articule en la investigación la formación de los saberes - en este caso, los saberes expuestos en el texto de Andry-, los sistemas de poder que regulan su práctica y el modo en que los individuos se desarrollan en torno a ella, es un modo de adentrarse en el laberinto de la historia de la ortopedia, de escribir y repensar la historia de ciertas instancias del inicio de la ortopedia infantil, al menos desde el momento en que es llamada así por primera vez.

Plantear ciertos problemas teóricos y ciertos pasajes significativos en la historia implica interrogar y problematizar una sociedad. No sólo observar esas prácticas o sólo leer esos discursos, sino poder registrar la voluntad de quienes los llevan a cabo y la estrategia de quienes los sostienen. Pensar cómo se reforzó la necesidad de un cuerpo recto, erguido en tanto sano y saludable, no por la negación de la materialidad del cuerpo, o de la fisiología o la anatomía, sino justamente inscripto en ese cuerpo y no como una ideología o un vago pensamiento, sino como una creciente red que inscribe al cuerpo un nuevo orden, en la que se insita a la formación de discursos y conocimientos y se refuerzan los controles, todo esto articulado entre sí según estrategias de saber y poder.

Poder y saber se articulan en el discurso. El discurso no se divide con claridad en lo aceptado y lo rechazado, sino que está constituido por múltiples elementos que se despliegan en diferentes estrategias y que implican variantes en los efectos que pueden constituir según el momento, el individuo, el contexto. El discurso puede funcionar como instrumento tanto como freno y punto de partida para una construcción opuesta. Más aún en el interior mismo de una estrategia los discursos pueden enfrentarse entre sí.

Este crecimiento discursivo se da disperso en varios focos, en diferentes formas y enlazados en una compleja red, que presenta a cada momento la problemática de la prevención y corrección del cuerpo infantil en un campo de constantes tensiones y oposiciones. El planteo de soltar las fajas de los niños, por ejemplo, denota en esta aparente liberación la presencia de la mano del adulto y el control del cuerpo a cuerpo de los padres con sus hijos en una nueva sujeción del cuerpo infantil.

\footnotetext{
${ }^{2}$ Experiencia: “correlación dentro de una cultura, entre campos del saber, tipos de normatividad y formas de subjetividad” (Foucault; 2003; 8).
} 
"Le colocaban primero al bebé una camisita de lienzo grosero que formaba muchos pliegues y frunces y encima una mantillas; después le pegaban los brazos contra el pecho y le pasaban bajo las axilas una banda ancha que le bloqueaba brazos y piernas. El lienzo y las bandas se replegaban entre los muslos, y contenía el conjunto una banda circular apretada al máximo desde los pies hasta el cuello"

(Badinter; 1991; 99)

Se fajaba a los niños por temor a sus cuerpos blandos, por la aspiración de que fueran fuertes, derechos y bien formados. Las prácticas correctoras de Francia hasta inicios del siglo XVIII materializan la importancia de la rectitud mediante la utilización por parte de los niños de un corsé (provisto de ballenas rígidas, cosidas sobre la envoltura de una tela ajustada) que mantiene y protege la forma adecuada del cuerpo.

Esta práctica, familiar ya en siglos anteriores -y revalorizada en particular durante el XVII bajo la seducción de la mecánica y la geometría - tiene la lógica del modelo de un contorno apretado que desde afuera impedirá el desvío de la morfología. Tal como la imagen del árbol sujeto con el tutor, si se lo mantiene recto mantendrá esa postura, si se lo deja curvar se deformará en su crecimiento. A mediados del XVIII se dan a conocer textos de intelectuales sofisticados que narran con admiración el modo de crianza de los niños en las tierras salvajes y exóticas: una crianza natural que deja libre el cuerpo del niño. Al mismo tiempo que se ordena amamantar a los hijos se solicita entonces que dejen sus cuerpos más móviles, que los libren de las fajas en su uso extremo.

¿Cómo esta aparente liberación del uso de las fajas en el cuerpo del recién nacido se desplaza precisamente hacia la formación de un cuerpo altamente sujeto y organizado? ¿Será acaso posible pensar en un cuerpo desorganizado sin sujeción? ¿Qué factores históricos apuntalaron este anclaje de cuerpo? ¿Cuál es el tipo de pensamiento que sustenta los modos de actuar sobre el cuerpo infantil? ¿De qué modo las mismas causas que apuntalaban el uso de las fajas pasaron a ser las causas de su prohibición? ¿Cómo y bajo qué necesidad se construye el concepto de cuerpo fuerte?

No se trata aquí de pensar el sacar la faja como una liberación absoluta del cuerpo, o de pensar estas nuevas formas de producción del cuerpo en tanto formas de 
represión, se trata más bien de observar, de indagar el modo posible en que se armaron estos mecanismos en tanto mecanismos positivos productores de saber, multiplicadores de discursos, y a partir de ello observar sus condiciones de inicio, su forma de funcionamiento y sus redes de distribución en la población. Observar las estrategias de poder en la construcción del saber de la ortopedia infantil, en un inicio que tiende a distinguir lo normal de lo patológico, delimitando lo más-menos desviado, lo poco razonable y aquello que está por fuera de los valores estéticos, todo aquello extraño que queda excluido, por fuera de lo deseable, de lo admitido. El problema de la apta conservación de los hijos parece ser cortejado principalmente por la literatura médica -al menos en una primera instancia-, y el énfasis se concentra en la arquitectura de los cuerpos.

Parte de los elementos que se abordan en este estudio no surgen inauguralmente en la época que nos ocupa, y muchos de ellos pueden rastrease hasta la Antigüedad Clásica. Es el caso de ciertos conceptos que de algún modo podemos leer en el texto de Andry: la conveniencia de la obediencia del niño hacia el adulto para su adecuada formación, la importancia de ejercitarse a uno mismo para transformarse, el dominio de sí, la cualidad del cuerpo constituida a partir de cierto orden y templanza, las preguntas de la medicina y la filosofía griega acerca del cuidado del cuerpo, la noción del régimen en tanto modo de vivir con sus detalles del empleo del tiempo, el dominio de los ejercicios, los alimentos, el descanso, etc. De todos modos, si bien en algunos momentos del trabajo se indagan hechos históricos anteriores al siglo XVIII, esta investigación queda acotada al siglo en que se edita L'orthopédie...

Lo particular del presente trabajo se instaura, entonces, en poder profundizar la lectura del texto de Andry desde la perspectiva de otros textos que de modo directo o indirecto permiten pensar la particularidad del cuerpo infantil en el siglo XVIII bajo la aparición del primer libro que nombra a la ortopedia, tal como ya ha sido expuesto.

Si bien los textos de historia de la ortopedia no rescatan a Andry más que por la presentación de la imagen del árbol con el tronco torcido sostenido por un tutor $^{3}$ (véase imagen en pág. 9) y por la introducción del término ortopedia, de todos modos y por eso mismo resultaron de gran utilidad. Consignamos aquí los principales textos desde cuyas perspectivas hemos abordado la lectura de la obra de Andry:

\footnotetext{
${ }^{3}$ Véase pág. 6.
} 
Corregir el cuerpo, de Vigarello, es un texto centrado en el estudio del modo en que las prácticas del ejercicio físico -en tanto pedagogía del cuerpo- se desarrollaron entre 1760 y 1960 dando un sentido histórico a la proyección de la atención hacia la rectitud y morfología del cuerpo. El término pedagogía, para el autor, permite abarcar más allá del pensamiento y las ideas: son también las imágenes, gestos y preceptos que con mayor precisión y seguridad dan forma a las normas en que se inscribe el cuerpo.

El recorrido del texto de Yalom, Historia del pecho, da cuenta del aspecto sagrado y sexual del pecho a lo largo de la historia. Indaga en profundidad su valor en diferentes culturas, y la relación del pecho con la sexualidad, la medicina, la exigencia de la maternidad, la muerte y la producción industrial. Su lectura ha sido fundamental para el desarrollo de este trabajo, en particular para el abordaje del capítulo 5. También para este capítulo ha sido importante la lectura de textos de historia y el aporte de Badinter con ¿Existe el instinto maternal?, a partir del cual nos fue posible indagar el lugar de la mujer y la maternidad.

Los textos de Agamben, Lyotard y Kohan nos permitieron abordar la problemática de la infancia tal como fue y es pensada, incluso como puede llegar a ser pensada.

El capítulo referente a los cuerpos bellos toma en particular Historia de la belleza de Vigarello, un estudio que reseña las transformaciones de las variaciones de los cánones de belleza y describe los aspectos valorizados y despreciados en relación al cuerpo y el arte de embellecer desde el Renacimiento hasta la actualidad. También el texto de Danto, El abuso de la belleza, si bien situado en un momento más actual, problematiza la relación entre arte, belleza y estética.

Los textos de Foucault han guiado, de algún modo, no sólo la elaboración de parte de los capítulos, sino fundamentalmente la metodología y el enfoque de una mirada política sobre la lectura del texto de Andry. 


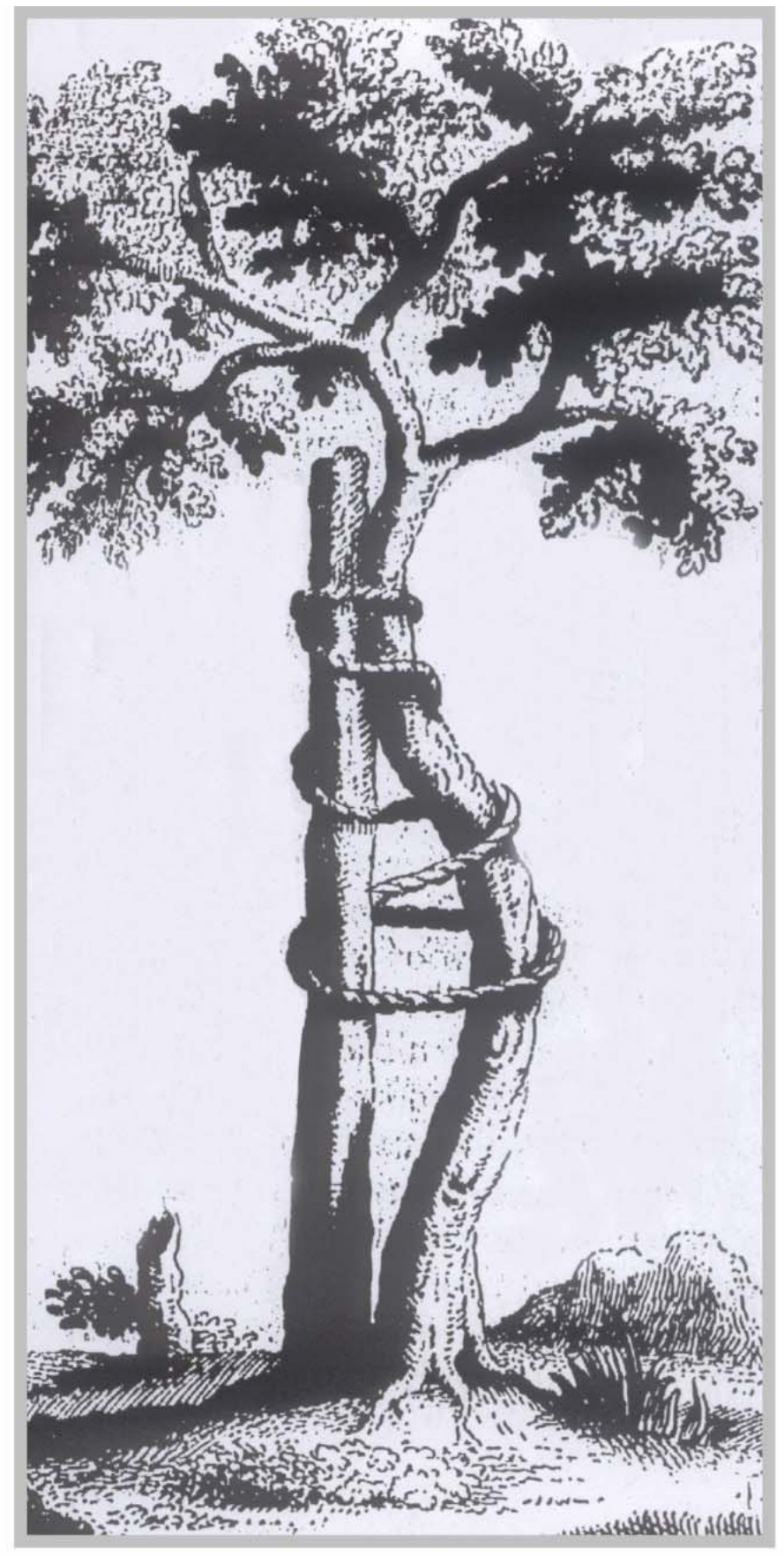

Imagen del árbol con el tutor (Andry, LIII; 253) 


\section{Contexto}

Hasta el siglo XVII la figura del padre y marido era la continuación del mandato divino. Así como Aristóteles demostró que la autoridad es natural y que un hijo es imperfecto en la medida que aún no está constituido, San Pablo recomienda a las mujeres del hogar mantener la conducta adecuada de inferioridad guardando silencio y modestia. La moral eclesiástica reafirma la subordinación de la mujer. Al padre soberano se debe la sumisión y dependencia de los hijos. Desde el punto de vista jurídico, la Iglesia y el Estado intervienen progresivamente desde finales de la Edad Media, cada vez más, en el gobierno de la vida doméstica.

El cuerpo se constituye en centro de interés en diferentes instancias de la historia y la cultura. Sin embargo uno de los elementos que se resaltan durante los siglos XVII y XVIII hacen referencia a la docilidad y las técnicas en torno a ella. (Foucault; 1989; 140). Lo particular es entonces la minucia con que se impone el poder de la organización de las fuerzas sobre el ejercicio del cuerpo: se regulan y codifican los movimientos en el tiempo y espacio. Se potencia una economía destinada a mejorar la eficacia del cuerpo basada en la relación de la docilidad con la utilidad de los cuerpos. A esto hace referencia Foucault al destacar la dominación de la disciplina en los siglos XVII y XVIII, esto es, un modo de relación con el cuerpo que trabaja de modo simultáneo y encadenado a la obediencia y su utilidad. Se recompone la organización del cuerpo en una anatomía política que trabaja sobre un cuerpo que debe ser productivo, que debe aumentar su utilidad en términos de la economía de la fuerza del cuerpo, con acondicionamientos muchas veces mínimos y sutiles en su apariencia.

La disciplina no es un invento de la época, lo que sucede durante los siglos XVII y XVIII es una acentuación en sus técnicas con la instauración y el aumento de instrumentos más precisos. La disciplina se centra en la distribución de los individuos en el espacio: a cada individuo su parcela. Se crea un espacio útil para cada individuo, -espacio que a su vez permite localizarlo-, se distribuye e individualiza la fuerza de trabajo. La organización escolar es ejemplo de esto, que a mediados del siglo XVIII acentúa una nueva modalidad que jerarquiza y economiza el modo de aprender. Estos rangos van complejizando la arquitectura misma, marcando lugares 
que indican en sí mismos su valor con el fin de garantizar la obediencia y sus procesos. Observar, clasificar sistemáticamente, separar y dividir ha sido la preocupación del siglo XVIII. Es el armado de un cuadro que es a la vez una técnica de poder y un procedimiento de saber (Ibíd,1989; 152). La utilidad del tiempo busca una precisión que no desperdicia el tiempo empleado. Se definen programas programas como los que también Andry propone - que ajustan el cuerpo a imperativos temporales. El tiempo penetra al cuerpo, y su eficacia queda definida en la precisión de cada detalle y cada gesto en relación a la totalidad del cuerpo en una duración tan rápida y eficaz como sea posible. Se procura dejar de lado la dispersión del tiempo y se enfantiza sobre su uso provechoso: el tiempo debe administrarse en función del concepto de favorecer el progreso de las sociedades. La disciplina es un poder modesto y sutil de un control económico ajustado y permanente que fabrica individuos; es un conjunto de técnicas en virtud de las cuales los sistemas de poder se centralizan sobre los individuos. Es el examen permanente.

Los procedimientos disciplinarios hacen del ejercicio de la observación y diferenciación un modo de control. Es un sistema donde se visualiza más al niño (al igual que se visualiza al loco, al delincuente y al enfermo) que al adulto. Se mejora la vigilancia, se la especifica en pos de una mejor funcionalidad. Más anónimo y funcional se vuelve el poder, mayor individualización por observación, vigilancia y medidas que a través o de la comparación buscan aproximarse a la norma. La disciplina busca aumentar el potencial del individuo en el sentido de aumentar el rendimiento y las ganancias en el menor tiempo posible, y "hace que entren los cuerpos en una maquinaria y las fuerzas en una economía" (Foucault; 1989; 213). La disciplina trabaja, avanza en pos de fabricar individuos útiles, ejerce su control más sobre el modo en que el proceso se desenvuelve que sobre el resultado de una acción.

En el SXVIII se desarrolla un arte de la observación del cuerpo humano en tanto eficacia y ajuste de los movimientos en el tiempo. Aparecen funciones laborales y militares tales como la del contramaestre, el capataz que observa cómo hacer mejor cada movimiento en pos del trabajo precisado, el suboficial en el ejército que trabaja sobre las maniobras y la reorganización de los movimientos de los soldados para lograr una mayor precisión y adecuación al tiempo. Pero no es suficiente observar los movimientos: se vuelve preciso vigilarlos bajo una pirámide de control permanente en un registro continuo. El único modo posible entonces de velar por la correcta 
conformación del cuerpo del niño es vigilarlo de cerca, y los encargados de esa función deben ser los padres, en particular la madre.

Entre los años 1715 y 1774, Luis XV, nombrado al inicio de su reinado como le bienaime, ocupa el trono de Francia y Navarra. El relato de los primeros años de su vida guarda ya un lugar particular en la historia del cuidado de la infancia ya que gran parte de su familia, posibles sucesores de la corona, mueren por viruela y él es salvado por su institutriz, Madame de Ventadour, quien prohíbe sangrar al infante y se pone al cuidado del niño durante su enfermedad.

Durante el siglo XVIII, una de las principales preocupaciones se centra en la alta tasa de mortalidad durante el primer año de vida de los niños y en los escasos cuidados hacia los lactantes. A horas o días de recién nacido, el niño es entregado a la nodriza. Sale de su lugar de nacimiento sin certificado ni documento que dé señal de su paradero y es trasladado a la casa de una nodriza quien suele amamantar a varios niños simultáneamente provocando, entre otros problemas, una mala calidad en la leche, por lo cual los pequeños más frágiles no logran sobrevivir. De acuerdo con las cifras de Lebrun, la mortalidad infantil en Francia entre los años 1740 y 1749 es del 27,5 \%. Cada mil niños que nacen 720 sobreviven el primer año de vida y sólo 525 llegan a cumplir los 10 años.

La preocupación por el lactante y los modos de prevenir la alta tasa de mortalidad en el primer año de vida aumenta al tiempo que se destaca su fragilidad: comienzan a modificarse y recrearse los gestos que rodean al lactante. En 1773 (Badinter; 1991; 112) la policía da órdenes de mejorar los carruajes que trasladan a los bebés y sugieren a las nodrizas que sean ellas quienes los acompañen en los viajes para que no caigan en el camino: las normas de higiene no aprueban niveles elementales. La estadía del niño con la nodriza suele llevar 4 años. En las clases altas, el niño será luego entregado a una gobernanta hasta los siete años, y si es varón continuará su educación con un preceptor: la estancia de los niños en la casa de sus padres es de apenas unos años.

Desde mediados del siglo XVIII abundan las publicaciones que instan a las madres a que amamanten y críen ellas mismas a sus hijos, que se ocupen de quienes serán la riqueza del Estado. Médicos, moralistas, funcionarios eclesiásticos unifican sus discursos en pos del amamante como nueva tarea llena de promesas de felicidad, 
discursos que destacan a su vez el rol primordial de las madres como garantes de la supervivencia de sus hijos.

Surge la demografía y el creciente interés de una Nación que quiere ampliar su población y fortalecer su producción en los albores de una era industrial. Un país fuerte y potente pasa a ser sinónimo de un país muy poblado: se imponen nuevas exigencias a los individuos en tanto fuerzas productivas. La noción de progreso se expande y el temor por la degeneración de la población crece de manera paralela: es necesario restituir mayor firmeza al cuerpo. El concepto de la degeneración de los cuerpos comienza a ser analizado en un aspecto histórico de la especie y en relación a la urbanidad. Se considera que el territorio, el clima y los hábitos alimenticios son los factores que marcan los cuerpos. La noción de degeneración, en el siglo XVIII, es asociada a debilitamiento y degradación (Vigarello; 2005; 30), al tiempo que se fortalece la conciencia de perfeccionamiento de la forma de los cuerpos.

Luis XV destina recursos para que la salud y el crecimiento de los niños prosperen. La preservación de los niños pasa a ser un tema de Estado; hacer posible la vida implica para el Estado crecimiento, bienestar, seguridad y riqueza. Algunos autores plantean que el niño adquiere a mediados del siglo XVIII un valor de mercancía, adquiere el valor de germen de una economía potencial en términos de futura mano de obra. Ya en el siglo XVII los niños abandonados comienzan a ser objeto de interés para el Estado, que crea los primeros asilos para niños abandonados con el fin de restringir el infanticidio.

Desde la política y la economía, se refuerza durante el mil setecientos una mirada sobre el cuerpo no esencialmente teórica, sino centrada en el análisis, la contabilidad, la clasificación y especificación centradas en los aspectos causales y cuantitativos (Foucault; 2002; 33). El cuerpo se administra no en tanto un rigor que reprima sino a partir de reglamentaciones vehiculizadas en discursos provenientes de la medicina, la política, del personal próximo al cuidado de los infantes.

El siglo XVIII plantea la problemática económica y política de la población en cuanto a técnicas del poder: la población en relación a la capacidad de trabajo, la mano de obra, la producción de riquezas, la regulación de los procesos biológicos del hombre-especie, el cuidado del equilibrio global. Foucault muestra la aparición, durante la segunda mitad del siglo XVIII, de una nueva tecnología del poder: la biopolítica; tecnología que no sólo no excluye la 
disciplinaria sino que la integra, la engloba. Son dos tecnologías de biopoder que al tiempo que presentan cierto desfasaje cronológico, se superponen en un entramado que el texto de Andry nos permite observar, y que desarrollaremos en los próximos capítulos de este trabajo. El problema político es justamente "el de la relación entre el uno y la multitud en el marco de la ciudad y de sus ciudadanos" (Foucault; 1996; 34). La cuestión central del inicio del liberalismo no es entonces la relación con el mercado, sino el gobierno de la vida sobre la población, la permanente y compleja tensión entre la libertad y la seguridad de este nuevo objeto de acción y análisis del siglo en cuestión: la población. La problemática del gobierno corre entonces su eje de la relación hacia el individuo o el pueblo para centrarlo en la variables propias de la población y su especificidad: el estado de salud, la mortalidad y morbilidad, la duración de la vida, la formas de alimentación, la sobrevida de los recién nacidos, la fecundidad y la vivienda. Todas estas variantes pasan a inscribirse en un espacio de intersección entre los movimientos propios de la vida y los efectos particulares de las instituciones (Id.; 2002; 35). Los mecanismos de poder del mil setecientos se centran en la vida de los hombres en tanto cuerpos vivientes, y el ejercicio del poder se instaura en el orden de la normalización tanto de los individuos como de las poblaciones. La norma tiende a homogeneizar, incluye un principio de clasificación y un principio de corrección. No implica la polaridad de la ley, tiene graduación (más/ menos normal): es un principio de funcionamiento adaptado y ajustado, es la regularidad que se opone a la desorganización, a lo patológico. La clave del poder no es entonces la disciplina, sino la normalización que se ve reflejada en la politización de la vida, el gobierno de la vida. Es un proceso de normalización a través de las técnicas de examen, con la intención de que los individuos introyecten la relación de vigilancia, que cada uno termine vigilándose a sí mismo. Lo particular del planteo de Foucault es que para él lo que realmente importa en relación a nuestra actualidad, a nuestra modernidad, es la gubernamentalidad (gobernar en tanto disponer de la vida biológica), y no el Estado o la estatización de la sociedad.

El biopoder es un elemento indispensable para articular la introducción de los cuerpos en el aparato de producción y la regulación constante del equilibrio de los fenómenos de la población a las exigencias de los procesos económicos. El poder, para Foucault, es el nombre que se presta a una compleja situación estratégica en una determinada sociedad (Ibíd.; 2002; 113). Poder pensado no en la forma 
unidireccional de gran dominación, como si partiera de un punto único de soberanía hacia cada individuo, sino un poder concebido en términos dinámicos que se produce en cada momento en la relación misma entre las partes, en la transformación que esos enfrentamientos sutiles y permanentes modifican.

El iluminismo destaca la libertad al tiempo que impone las disciplinas. Una de las tareas de la ilustración reside en multiplicar los poderes políticos de la razón: se plantea la relación entre la razón y la experiencia al tiempo que se evidencia el vínculo entre la racionalización y los abusos de poder político. El iluminismo despierta la preocupación por qué es el presente, por la cuestión de la actualidad y la inscripción en la historia. La ilustración se nombró a sí misma, es un proceso cultural que tomó conciencia de sí y se situó respecto de un pasado y de un porvenir; es un acontecimiento que inaugura la modernidad europea y un proceso permanente en nuestro pensamiento en torno a la razón, la autoridad del saber y la voluntad. Si consideramos entonces la modernidad como un acontecimiento más que como un período histórico podemos entenderla en tanto la tarea de pensar y sentir en un modo presente, es la voluntad de captar ese instante heroico, un modo complejo que pone al individuo a pensarse y elaborarse en relación a sí mismo. Una relación reflexiva con el presente. 


\section{L'orthopédie ou l'art de prévenir et corriger dans les enfans les difformités du corps ${ }^{4}$}

L'orthopédie ou l'art de prévenir et de corriger dans les enfans, les difformités du corps. Le tout par de mohines á la portée des Peres et des Meres, et de tout les Perfonnes qui ont des Enfans á élever está firmado por «M. ANDRY, CONSEILLER du Roy, Docteur et Profeffeur en Médecine au College Royal, Docteur-Regent, \& ancien Doyen de la Faculté de Médecine de Paris, 06 » e impreso « Chez George Fricx à Bruxelles, Imprimeur de sa Majefté,1743 . Avec Aprobación et Privilege de Sa Majefsté». ${ }^{5}$

El texto es un excelente ejemplo de esta nueva articulación de la familia con la medicina que nos ofrece el siglo XVIII. Si bien ha sido escrito en el marco de la profesión médica, este libro escrito en francés y traducido luego al alemán y al inglés, está dedicado especialmente a los padres y a las personas encargadas de la crianza y educación de los niños. Es un texto práctico que propone con claridad reglas de conducta, que busca formar parte de la vida cotidiana de los individuos, insistiendo en reflexiones que alientan a los padres a tomar el mando en la vigilancia sobre los niños y a educarlos en la tranquilidad y la alegría.

Una primera lectura del texto pone de relieve la transformación del estilo de escritura en relación a otros textos de ortopedia y el desplazamiento de la frontera entre medicina y literatura hacia un lugar donde la literatura (arte) y la medicina (ciencia) son en cierta manera indiscernibles, donde no se puede distinguir entre el concepto y la vida.

En su aspecto técnico, se observan las exigencias funcionales de un discurso que debe producir su verdad, recurriendo a todo tipo de estilos que den a su texto un orden dentro del régimen del saber. Si bien promueve una moderada comprensión de las deformidades en el cuerpo del niño, es recordado en el ámbito de su especialidad más por el aporte del nombre mismo de la ortopedia y de la imagen del árbol con el tutor (véase imagen en pág. 27), que por la especificidad de su aporte científico. El

\footnotetext{
${ }^{4}$ Véase imagen en pág. 26.

5 "La ortopedia o el arte de prevenir y de corregir en los niños las deformidades del cuerpo. Todo por medios al alcance de los Padres y de las Madres, y de todas las personas que tienen niños para educar. POR M. ANDRY, CONSEJERO del Rey, Lector y Profesor en Medicina en el Collège Royal, DoctorRegente, y ex Decano de la Facultad de Medicina de Paris VI." "Georges Fricx, Impresor de Su Majestad, Bruselas, 1743. Con Aprobación y Privilegio de Su Majestad”.
} 
autor utiliza un lenguaje coloquial, accesible, incluye numerosas citas bíblicas e invocaciones a Dios y ejemplos de situaciones comentadas o vividas por importantes poetas antiguos, reyes y personajes de la mitología greco-romana que refuerzan o ejemplifican los abordajes de su obra. Recurre con frecuencia a la utilización de metáforas y se mantiene más próximo al vocabulario de la vida diaria que a la terminología específica de la anatomía. Mantiene una atmósfera descriptiva que diluye el límite entre un texto de prescripciones médicas y un tratado de belleza, renovando las referencias de la estética corporal. Establece a su vez una continuidad entre lo físico y lo espiritual, recurriendo a la psicología del niño y a la de sus padres o personas encargadas de la crianza y educación.

El autor propone preparaciones medicinales, ungüentos, baños y ejercicios que confían su eficacia a la simple repetición. El texto detalla la creciente importancia por la nueva arquitectura del hogar, su estructura y funcionamiento: la dimensión de la vivienda, la reorganización espacial, la descripción de muebles adecuados (véase imagen en pág. 28) para esta nueva pedagogía del cuerpo; insiste también en la importancia de los elementos del medio ambiente (agua, aire, suelos) para la correcta conformación del cuerpo del niño. El libro de Andry se divide en dos tomos en los que los temas se organizan de la siguiente manera: ${ }^{6}$

\section{Primer tomo:}

Prefacio (4 artículos extensos )

I) Prefacio propiamente dicho

II) Comentarios acerca de Pédotrophie

III) Comentarios acerca de La Callipédie

IV) Presentación del plan de L'ortopédie ou l'art de prévenir et corriger dans les enfans les difformités du corps

\section{Libro Primero (LI)}

Nociones generales del exterior del cuerpo

\footnotetext{
${ }^{6}$ Debido a que la extensión del índice de Andry es de más de 10 carillas, sólo resumimos aquí la organización de los temas.
} 


\section{Libro Segundo (LII)}

Modos de prevenir y corregir en los niños deformidades del talle

Libro tercero (LIII)

Deformidades de los miembros

\section{Segundo tomo:}

\section{Libro cuarto (LIV)}

Deformidades de la cabeza

Presentamos a continuación un breve análisis de la estructura del texto de Andry que nos permitirá abordar la lectura de sus elementos más significativos en relación al tema de nuestra investigación.

\subsection{Las fuentes}

El libro comienza con un extenso prefacio en el cual el autor cita y describe dos textos fundamentales para su obra, a partir de los cuales propone un nuevo modo de nombrar este tratado: la ortopedia, más específicamente la ortopedia infantil.

Estos textos son Pédotrophie, Traité fur la maniere de nourrir les Enfants a la mamelle ${ }^{7}$, escrita originalmente en latín por Scévole de Saint Marthe -de familia de humanistas y eruditos del idioma francés- en 1584 y La Callipédie. Traité fur les mohines d'avoir de beaux Enfants ${ }^{8}$, escrita en latín y luego traducida al francés por Claude Quillet en 1656.

El término ortopedia está compuesto, según Andry, a partir de dos términos griegos: orthos que significa "derecho, exento de deformidades" y Paidion, que significa

\footnotetext{
7 “Pédotrophie. Tratado sobre la manera de nutrir a los niños amamantando”.

8 "La Callipédie. Tratado sobre el modo de tener hijos bellos".
} 
"infante". Da cuenta, en un solo término, de su propuesta de enseñar diversos modos de prevenir y de corregir en los niños las deformidades del cuerpo (Andry, LI;.iv) ${ }^{9}$.

\section{1.a. La Pédotrophie}

En el segundo artículo, Andry aborda el texto de Sainte Marthe, La pédotrophie. Traité fur la maniere de nourrir les Enfants a la mamelle refiriéndose a él como un excelente Poema (Ibid.; LI; XIVI), una obra perfecta para la Poesía, escrita por el autor en las colinas de unas rocas inaccesibles, cuyo agradable horror daban a su espíritu y su mente un furor divino. La pédotrophie comienza con una invocación a las musas y al Dios Apolo, está dedicada al Rey Enrique III y pide que el hijo del Rey pueda ser criado bajo las indicaciones que el tratado propone.

Andry describe los elementos centrales de este texto, que en su comienzo detalla las obligaciones de una madre encinta: que no use ropas ajustadas, que regule sus pasiones evitando las tristezas y los excesos de euforia, que evite las danzas y que descanse y trabaje de manera proporcionada. Detalla el tipo de alimentación pertinente así como también la importancia de beber agua y no vino en exceso, ya que cualquier tipo de abuso quedará marcado en la piel del bebé (Ibíd.; LI; XII). Sugiere a la madre seleccionar la posición para el parto (aconsejando el modo vertical), y trae a colación el relato bíblico de la escena de Eva y la serpiente para explicar la causa del dolor del parto.

Sainte Marthe dedica todo un capítulo a la preparación para la recepción del bebé. Recurre reiteradas veces a licencias poéticas, utilizando metáforas de la naturaleza e historias mitológicas para describir elementos fisiológicos tales como la unión de la madre con el niño a través del cordón umbilical como lazo que dará libertad a cada uno de los cuerpos. Describe la importancia de criar un niño vigoroso, exento de debilidades, y la importancia de "rociarlo en vino "tras el parto, desechando la costumbre germana de bautizar a los niños en las frías aguas del Rhin al momento de nacer. El autor aconseja limpiar cada parte del cuerpo del bebé, "manejándolas dulcemente dándole a cada parte la forma y la rectitud que tienen que tener para componer un todo perfecto, tal como hizo Promethée, quien de su mano hábil forma al hombre a la imagen Divina" (Ibíd.;LI; XVII). Para después del baño, explica el modo

\footnotetext{
${ }^{9}$ Las citas del texto de Andry incluyen el libro al cual pertenece, ejemplo LI para el primer libro y a continuación el número de página que respeta su particular estilo (en especial en las referencias de la introducción) de enumeración .
} 
de frotar la piel del bebé para endurecer su cuerpo y poder colocar las bandas (fajarlo)que se utilizan para intensificar la rectitud y fortaleza del sistema músculo esquelético ${ }^{10}$.

Sainte Marthe se extiende sobre el modo de seleccionar una buena nodriza, a quienes se entregaba el bebé para la crianza: que viva en un lugar no demasiado apartado, y que al igual que la madre evite el vino, tenga gran control sobre sus pasiones, que le guste estar al aire libre, amasar el pan y realizar ejercicios. Que sepa de los hábitos alimenticios, que implican amamantar a demanda -con asiduidad y en pocas cantidades- y comenzar al octavo mes de vida con los alimentos sólidos, sin utilizar ácidos ni sustancias amargas para el momento del destete. Recalca la importancia del acunar y cantar al bebé para dormirlo, y del cultivo de la mente y el espíritu para lograr un niño que ante todo sea moderado: moderación que apure al niño lento y tranquilice al más rápido.

En la última parte de Pédotrophie, el autor invoca nuevamente a Apolo y pide ser iluminado para poder explicar los modos de curar las enfermedades que detalla: la inflamación umbilical, el insomnio, las úlceras, la tos, la sarna, la constipación del vientre, los cólicos, etc.

\section{1.b. La Callipédie}

Andry destina el tercer artículo del prefacio al segundo libro que es fuente esencial de su texto: La Callipédie. Traité fur les mohines d'avoir de beaux Enfants. Texto de cuatro tomos basado a su vez en La Pédotrophie, nombrada obra poética tan perfecta como Les Géorgiques de Virgilio. Andry presenta a Quillet como gran filósofo, sabio médico y excelente poeta. La Callipédie se centra en el modo de tener bellos niños, en la preparación del niño desde antes de su nacimiento para determinar y prever su integridad física y futura moral. Para la efectividad de su propuesta, comienza, con un análisis de los factores a tener en cuenta para la concreción de una buena pareja: que los amantes no tengan una diferencia importante de años, que no sean demasiado jóvenes, que no tengan importantes

\footnotetext{
${ }^{10}$ Cabe destacar que fue también práctica habitual en Argentina hasta las primeras décadas del siglo $\mathrm{XX}$.
} 
defectos físicos, que no sean extranjeros y que prefieran el mérito a la riqueza (Ibíd.; LI .lij). ${ }^{11}$

Qulliet describe con minuciosidad la relación entre el Zodíaco, las constelaciones y la constitución física y espiritual de los futuros padres que desencadenan las distintas combinaciones posibles de las parejas. Aconseja a los maridos cuidar de la tranquilidad de sus esposas, teniendo en cuenta que serán las madres de sus hijos. Detalla estaciones del año, signo zodíaco de los padres, ubicación de los planetas, horarios y momentos del día para concebir un hijo sin defectos ni deformaciones físicas, sugiriendo el vino que se debe tomar y la posición a mantener durante el coito en caso que se desee concebir un hijo varón según concepciones de antiguos anatomistas; consideraciones que Andry desechará en sus estudios.

Andry continúa explicando cómo el autor se extiende sobre las obligaciones de las madres embarazadas, para que no destruyan el fruto que llevan dentro (Ibíd.; LI .I x): deben huir de la melancolía, evitar objetos y situaciones desagradables para no imprimir marcas sobre el bebé, no danzar, evitar grandes movimientos, mantener pura la imaginación, recrear la vida al aire libre de acuerdo con las condiciones climáticas y prepararse para el parto en los últimos dos meses. Tal como es habitual en la época, Quillet recomienda fajar a los niños recién nacidos, pero no de manera muy ceñida, ya que esto podría darle una mala figura (Ibíd.; LI; Ixij) dado que la compresión excesiva del pecho y las costillas pueden desencadenar joroba en el niño.

Para finalizar, Quillet detalla las miserias del hombre durante los primeros años de vida (Ibíd.; LI; Ixiv) y reglamenta cómo formar bien al niño para tener una buena descendencia: ni bien comience el pequeño a balbucear debe inculcársele el temor al Gran Soberano, preferentemente cuando se oigan truenos en días de tormenta; que el pequeño aprenda a honrar a sus padres y tutores. Sugiere que estudie historia, letras e idiomas -preferentemente el francés-, leerle poesía y filosofía y evitar, en cambio, el acceso a las novelas. Recomienda guiar al niño en el ejercicio de la curiosidad, con particular interés en estudiar el sol y la tierra, la materia y los animales. Propone considerar al hombre como obra maestra de la Naturaleza y, en esa tesitura, equipara el Universo con el cuerpo humano: la cabeza es a los sentidos

\footnotetext{
${ }^{11}$ El texto está dedicado a Jule Mazarini, político italiano proveniente del campo de la religión nombrado ciudadano francés, que sucede como primer ministro de Francia a Richelieu durante los años del Rey Luis XIV.
} 
lo que Dios es a los ángeles, el vientre es comparado con el mar (Ibid.; LI; Ixvj), el sudor a la lluvia. Quillet se extiende en amplias consideraciones sobre el cuerpo y el alma: aunque el alma está expandida en todo el cuerpo y lo gobierna, ambas entidades no deben confundirse: el alma es al cuerpo lo que Dios es al mundo, y mientras el cuerpo sólo es para esta vida, el alma continúa en la eternidad. Pone especial énfasis en cultivar el espíritu y la mente y en ser útil para los otros, ya que el hombre nació para vivir en sociedad y en relación a esto considera las peculiaridades de las distintas naciones y sus habitantes: franceses, ingleses, daneses, italianos.

\subsection{El texto}

En el cuarto artículo del prefacio de L'orthopédie ou l'art... Andry presenta el plan de su obra, que está basada en el principio de cuidar la gracia del cuerpo siempre dentro de los límites que la razón prescribe y entendiendo que no es bueno descuidar el cuerpo al punto de dejarlo deforme, ya que esto implicaría ir contra la voluntad del Creador (Ibíd.; LI Ixxiij ${ }^{12}$ ). Andry destina su obra a los padres más razonables, para que puedan cuidar de los aspectos exteriores del cuerpo (de esas "deformidades a las cuales los niños pueden estar sujetos"), ya que de los aspectos internos se ocupa la medicina. El autor no pretende que los padres logren curar una sordera, pero sí que sepan, por ejemplo, mejorar el aspecto de una oreja de feas proporciones con modos simples y fáciles para prevenir y corregir en los niños las deformidades del cuerpo, logrando una perfección exterior. Una vez detallados los cinco artículos que constituyen el prefacio, el texto se organiza en dos tomos:

\section{Primer tomo}

El primer libro incluye 21 artículos dedicados a una noción general del exterior del cuerpo. Cada uno de ellos está dedicado a una parte del cuerpo -la cabeza, la nariz, las cejas, los ojos, los dientes, el cuello, el esternón, las clavículas-, con una terminología sencilla y de escasa complejidad técnica:... "al extremo de la base de la frente se elevan a cada lado, un pequeño montoncito de pelos en forma de arco, que lo llamamos cejas...". ${ }^{13}$ Describe la piel en tanto envoltura del cuerpo y finaliza la presentación de sus nociones principales con dos artículos. El anteúltimo está

\footnotetext{
${ }^{12}$ Se respeta el grafismo de la paginación del original.

${ }^{13}$ Las traducciones del texto de Andry son de Laura Atrajo, Natacha Nicora y Daniela Yutzis.
} 
destinado a las proporciones exteriores del cuerpo humano basadas en la ciencia de la mecánica: la perfección implica una simetría ajustada que se logra observar cuando el individuo logra una edad adecuada, en el hombre hecho (dans l'homme

fait ) (Ibíd.; LI 38 ). El autor resalta las reglas perfectas de la proporción de la naturaleza -similares a las de la arquitectura- y diferencia los extremos donde el cuerpo ya no está dentro de ese orden. En el último artículo, describe las variedades de belleza en otras culturas, resaltando su preferencia por las formas más razonables y universalmente más aceptadas: las francesas.

El segundo libro alude a los modos de prevenir y corregir en los niños las deformidades del tronco: clavículas, pecho, pelvis y vientre. Detalla los modos adecuados para resaltar un buen talle (véase imagen en pág. 29) y la rectitud deseada. Propone ejercicios (algunos en forma de juego), cargas, ungüentos y vendajes para ejecutar sobre los niños en tiempo favorable (especialmente antes de los 4 años) para reducirlos a lo que uno quiere (pour les reduire a ce que l'on veut ) (Ibid.; LII; 83 ). Aconseja muebles adecuados para el buen dormir, determina alturas de sillas y mesas en función de la postura correcta.

El tercer libro enumera las deformidades de las extremidades: brazos, manos, piernas y pies. Cita ejemplos narrados por historiadores de casos extremos tales como hombres con brazos que llegan hasta más allá de las rodillas. Diferencia las deformidades de conformación en el vientre materno respecto de las producidas en el parto o posteriores a él. Las primeras no tienen solución, incluso aquellas que son por culpa de la madre: como ejemplo, cita el de una madre embarazada que miró con detención una estatuilla de una mujer embarazada con brazos por demás largos, lo cual produjo la misma deformación en su hija (Ibíd.; LIII; 148 ). Las segundas, en cambio, requieren del trabajo de los padres: prescribe recetas, modos de frotar la pierna o el brazo, ejercicios por repetición y esfuerzo, detalles de modos de acarrear niños, descripciones de calzados, baños con aceite de gusano y caldo de tripas moderadamente caliente (Ibíd.; LIII; 161) y otras modalidades más para que los miembros de los niños estén bien hechos.

Incluye descripciones y tratamientos para manos sudorosas, pulgar de sastre, manos que los niños deforman con sus propios juegos y malos hábitos, lesiones en dedos provocadas por el frío. El libro continúa dedicando un artículo a cada tipo de deformidad de las uñas: uñas ganchudas que deben recobrar su forma natural, uñas superpuestas, demasiado espesas por exceso de alimento, caídas o que caen en 
lomo de burro, ásperas o desiguales, manchadas, partidas o agrietadas, pálidas en exceso.

El final del tercer libro hace referencia a las deformidades de los miembros relativas a la marcha, que deben ser tratadas, según la gravedad, con el modelado de la mano del adulto sobre el niño, con ejercicios constantes y con sacrificio, con el uso de vendas, fajas o compresiones mayores que regresen el cuerpo al eje tal como el tutor que se coloca al árbol joven.

\section{Segundo tomo}

El cuarto libro está dedicado a las deformidades de la cabeza (véase imagen en pág. 30), la parte más noble del cuerpo:

\footnotetext{
"La cabeza para estar bien hecha y ser considerada bien formada debe ser un poco redonda y horizontalmente un poco alargada, tener hacia delante y hacia atrás un pequeño saliente y ser un poco aplanada en los costados. Esta es la figura natural, pero se puede corromper por la manera en que se gobierna a los niños". (Ibíd.; LIV; 2)
}

Andry detalla las diferentes constituciones de la cabeza según el tipo de fajado que se practica en cada Nación. Describe las deformidades del cabello: su color, los cuidados básicos, los problemas en el cuero cabelludo, las puntas florecidas, los cabellos erizados. Detalla a continuación las deformidades de la cara: destina 15 artículos a las deformidades de las cejas (demasiado tupidas, espesas, rectas, unidas, erizadas, pelirrojas, con el arco interrumpido o muy elevado, etc) que incluyen 14 condiciones para que las cejas mantengan las formas adecuadas; en otros 13 artículos se ocupa de la nariz (incluyendo la nariz torcida por causa del mal modo en que las nodrizas limpian la nariz de los niños); otros 10 los destina a los párpados; 8 a los ojos; 4 a las mejillas; 3 a las orejas; 5 a los labios; 3 al mentón; 10 artículos a la piel del rostro; otros 10 a las encías; 5 a los dientes.

Los últimos artículos se ocupan de la lengua, y hacen referencia a los modos de revertir el mutismo, a los problemas en el lenguaje y a las deformidades en la voz, como el tartamudeo o los casos de hombres con voz de mujer o de mujeres con voz de hombre: 
"Nada debe ser minimizado en la educación de los niños, tanto en lo relativo al cuerpo como al espíritu, todo tiene sus consecuencias" (Ibíd; LIV.109)

Dentro del libro IV se incluye la conclusión de la obra: Andry insiste en la importancia de tomarse el trabajo de revertir los malos hábitos y la mala educación y acentúa la noción de las malas influencias de las nodrizas que transmiten mentira y venganza (comentario reforzado con citas del Eclesiastés, de Aristóteles y de poetas antiguos) y que son incluso capaces de generar epilepsia en los niños al transmitirles sus propios temores. 


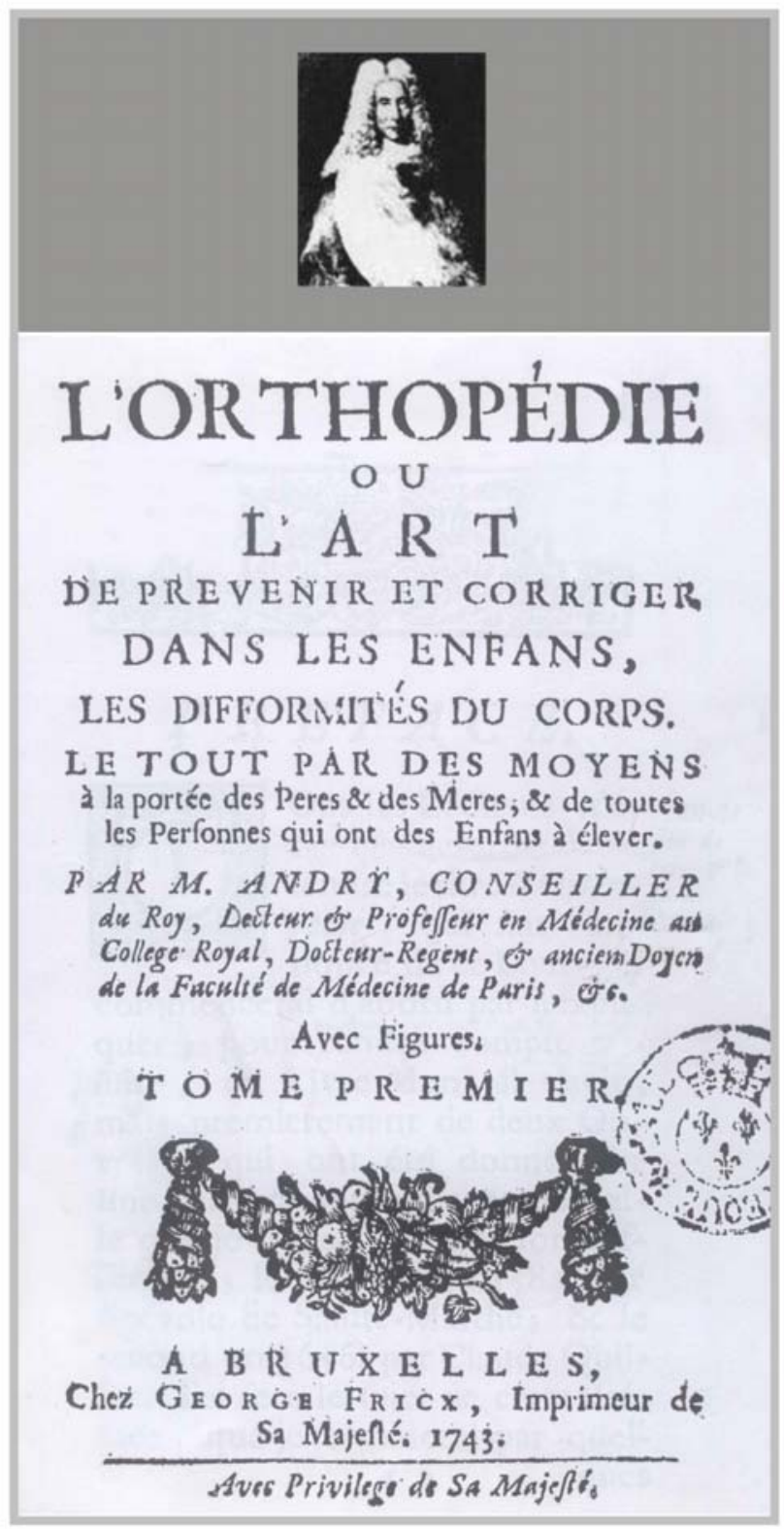

Tapa del texto de Andry y foto del autor 


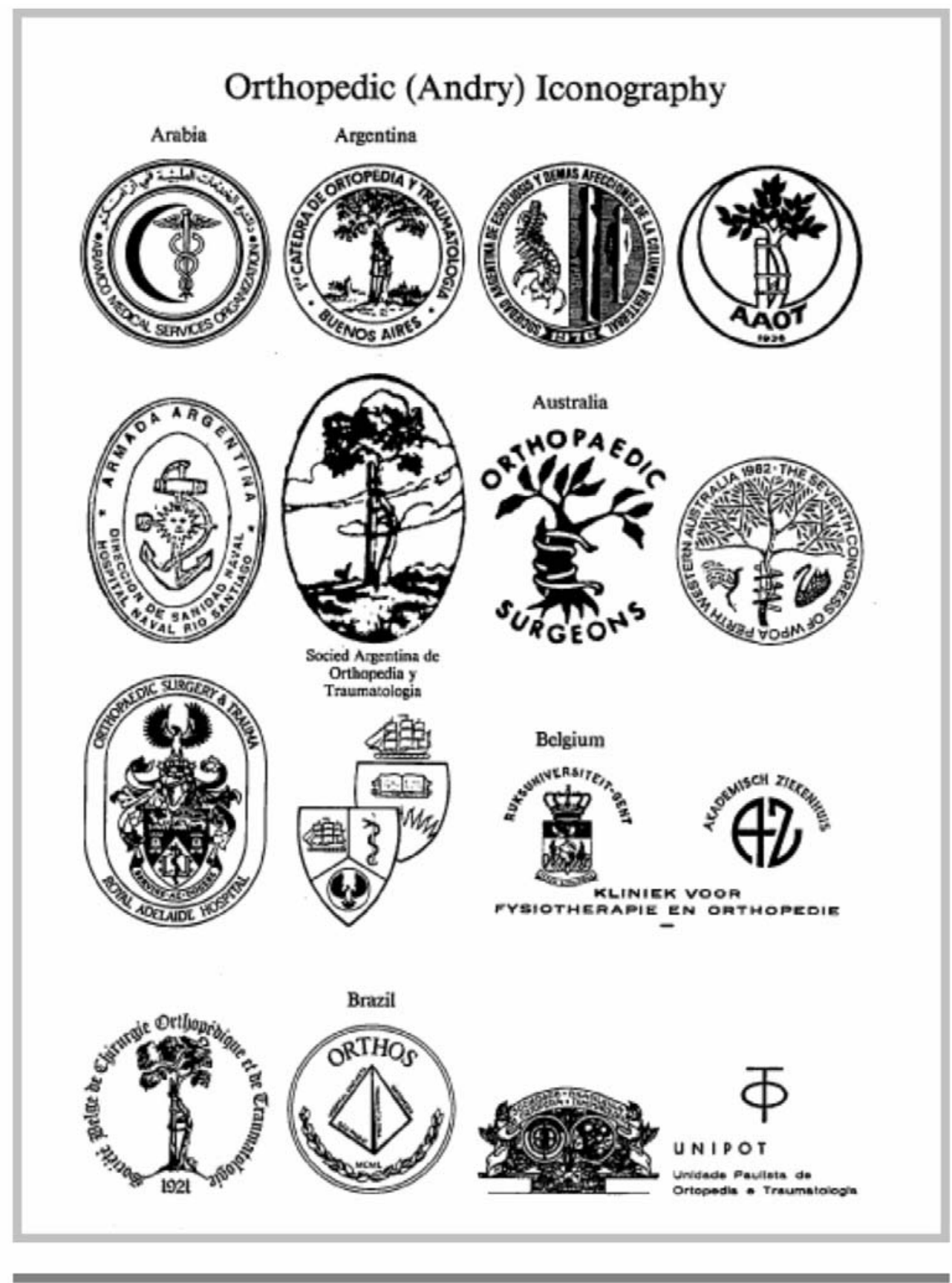

I magen del árbol con el tutor re-utilizada en instituciones pertenecientes al ámbito de la ortopedia en la actualidad. 


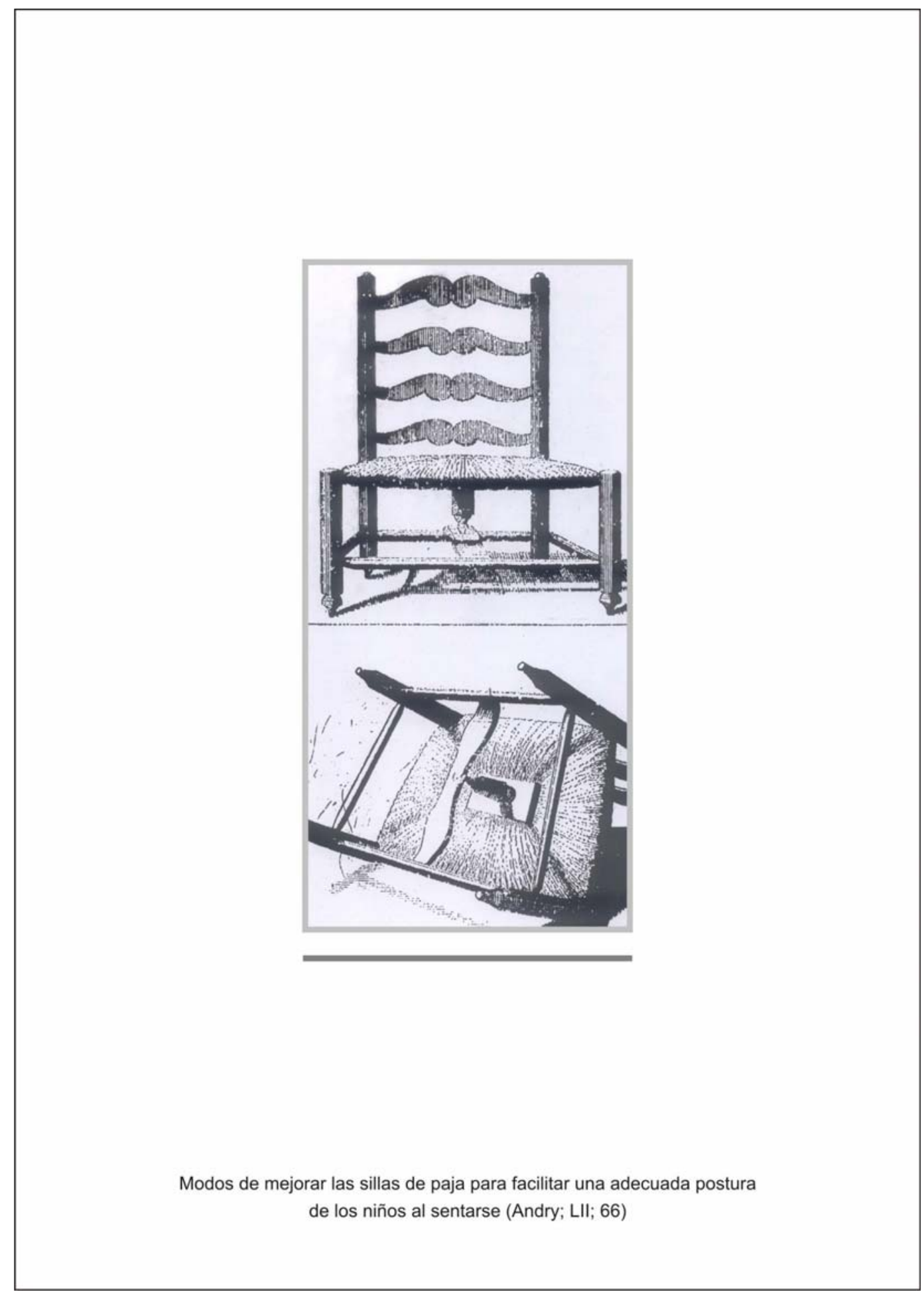




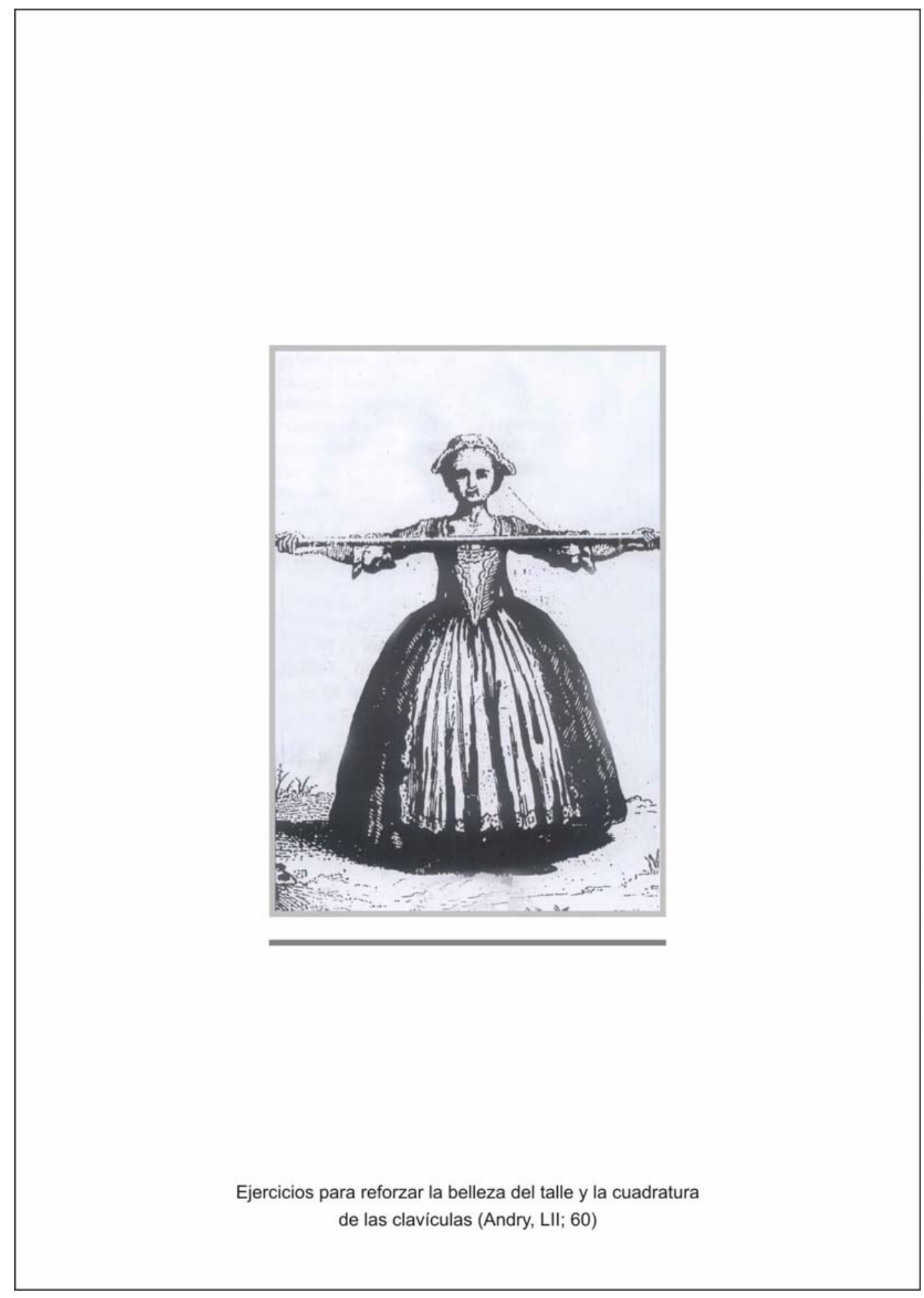




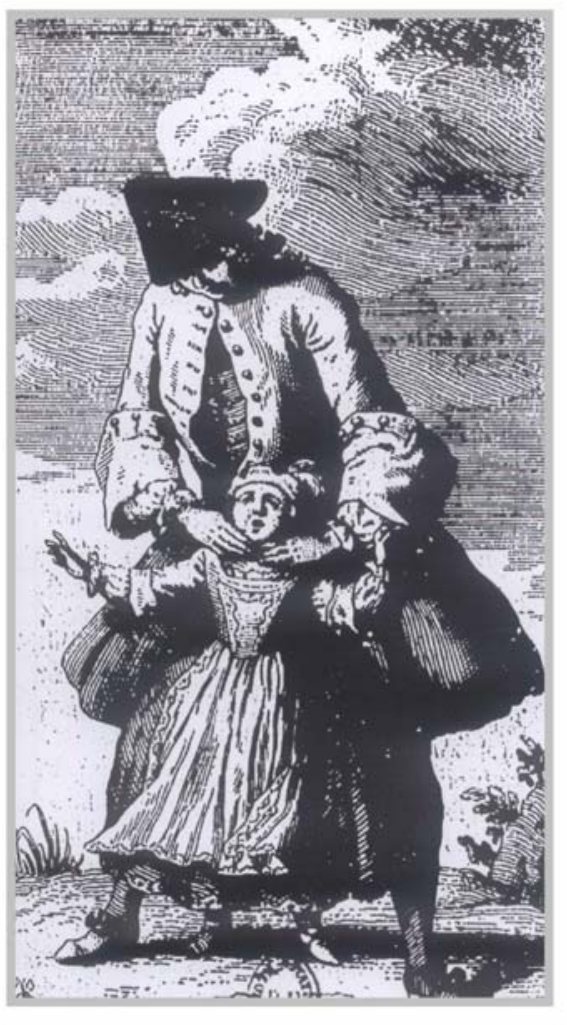

Mano del adulto en su intervención para la corrección de las deformidades de la cabeza en el niño. (Andry; LII; 86) 


\section{La medicina}

Hasta el siglo XVIII la medicina no se ocupó particularmente de mujeres ni de niños. De las mujeres embarazadas, del parto y ciertos saberes de crianza se ocupaban las viejas $^{14}$, un ámbito de la medicina asociado a la familia, similar a las nodrizas. Durante los siglos XVIII y XIX, la conquista de este espacio por parte de la medicina despliega un enfrentamiento que resalta dos puntos centrales: el amamantamiento y el ropaje del niño, sus fajas y corsé.

Las primeras obras próximas a la medicina infantil de finales del siglo XVI y del XVII se dirigen, además de a los médicos, a los padres, para que puedan asistir a los niños. Si bien el término pediatría surge en el año1872, cierta especificidad en la atención de la particularidad de la medicina para infantes comienza a ampliarse a mediados del XVIII. Los médicos dirigen sus discursos al personal de las instituciones al mismo tiempo que a las familias en un proceso de expansión de la medicina doméstica. Andry facilita a quienes están al cuidado de los niños un saber médico aplicable a las situaciones ordinarias, saber que sirve de guía para el modo de actuar en la vida cotidiana.

La medicina va dando cuenta del poder centrado en la intervención sobre la vida y no ya sobre la muerte. El modo de la vida, el control de los accidentes, los riesgos, las deformidades y las prevenciones posibles para una vida óptima no hacen más que realzar la vida misma. La problematización de la salud se centra en la búsqueda del mayor vigor y longevidad posibles, y en lograr un cuerpo fuerte que genere a su vez una buena descendencia (principios de la eugenesia). Este nuevo proceso de finales del siglo XVIII, que va ganando cada vez mayor terreno en los mecanismos administrativos y de gobierno del Estado, se centra en la medicalización ${ }^{15}$ especialmente de los niños y sus familias-, en la higiene y la presentación de la medicina como instancia de control social, como una técnica general de salud y ya no sólo como una técnica abocada al estudio de la enfermedades y su modo de sanación. El proyecto estatal de la organización de los matrimonios y familias es también un proyecto médico de gerenciamiento de la natalidad y fecundidad. Las

\footnotetext{
14 Término utilizado por Donzelot (1998; 22).

${ }^{15}$ Medicalización en tanto proceso que resalta la función política de la medicina, así como el avance indefinido de la medicina y el saber médico en la vida misma.
} 
exigencias para la elección de un matrimonio adecuado desbordan ya la cuestión de clase, tal como se observa en el texto de Andry.

Antes de continuar profundizando ciertos aspectos políticos de la medicina en el texto de Andry, y de observar el modo en que el saber refuerza -y más aún, prolonga- los efectos del poder, nos detendremos en ciertos aportes históricos que preceden y de algún modo acompañan la publicación de L'orthopédie....

Hipócrates (460- 370 a.c.) fue el primero en otorgar a la medicina una metodología sistemática y un lugar social al médico. A él se atribuye el Corpus Hippocraticum, una colección de 53 libros, escritos algunos por sus discípulos, como el caso de Peri Athron ("Sobre las articulaciones") en el cual describe varias luxaciones, los métodos posibles de reducción y las recidivas posteriores; Peri Agmon ("Sobre las fracturas") donde introduce la técnica de tracción continua, la inmovilización con férulas y la compresión con vendajes; Mokhlikos ("Palanca") cuyo título hace referencia a la mesa utilizada para reducir las fracturas y deformidades de la columna vertebral e introduce nociones anatómicas sobre huesos y articulaciones. Se le reconoce a Hipócrates una gran experiencia práctica en estas lesiones, así como también la presentación de los cinco conceptos principales de tratamiento de las fracturas (antisepsia, vendaje, reducción, entablillado y tracción) que refuerzan los poderes curativos de la naturaleza (vix medicatrix) considerados hasta entonces como el pilar escencial del tratamiento médico. En sus escritos se encuentran algunos datos de correcciones (como el caso del pie zambo) que dan cuenta de la atención que pone en ciertas deformaciones ortopédicas infantiles. Hipócrates basó su trabajo en la clínica y la investigación descriptiva mediante el examen sistemático del enfermo y el estudio de los factores que permitiesen llegar a un pronóstico sobre su dolencia, proceso durante el cual comenzó a diferenciar la medicina de la religión y la filosofía.

Le Traité des solides et des fluides ${ }^{16}$ es de algún modo una declaración inaugural a la medicina del siglo: trata allí temas como la circulación de los fluidos corporales y su retención, y la repercusión mutua entre los fluidos y las contracciones y relajaciones musculares, si bien en esta instancia es aún en parte el alma la encargada de encontrar una buena regulación de los flujos corporales. Transcribimos una cita de Andry que da cuenta del límite amplio y difuso de la noción de "humores":

“Ustedes permiten tranquilamente, padres y madres, que cualquiera apoye sus

\footnotetext{
${ }^{16}$ Malouin, Nicolás ,1712.
} 
labios a menudo muy sucios, sobre las mejillas tiernas y delicadas de sus hijos. Es una gran imprudencia, y es comúnmente causa numerosas agallas y descamaciones en el rostro, y otras suciedades peligrosas. Impidan pues que besen tan libremente a sus hijos, y cuando, por esos besos o por otras causas, su rostro haya contraído las suciedades que acabamos de mencionar, eviten emplear cualquier remedio que pueda hacer volver hacia adentro el humor que las produce.

Tomen más bien el partido de no hacer nada, antes que hacer algo inadecuado; un poco de leche tibia es todo lo que la prudencia permite entonces aplicar en las mejillas." (LI, 126)

En 1628 William Harvey descubre la circulación de la sangre, y, en 1652, Thomas Bartholin el sistema linfático. Estos nuevos estudios abren de modo progresivo y lento el pasaje hacia la medicina celular del siglo XIX (Yalom; 1997; 260).

Luego de Descartes, el siglo XVII revela una visión maquinal del cuerpo que se limita a corregirlo mediante prácticas compresivas y dista aún de proponer una organización del cuerpo que pueda ser modificada por el ejercicio físico. El mecanicismo en el campo de la medicina tiene sus bases en la anatomía renacentista con la obra de Giovanni Alfonso Borelli (1608-1679), quien aplica las leyes matemáticas al estudio de la mecánica animal y sus movimientos: considera por primera vez los huesos como palancas y estudia la contracción muscular. William Croone y Thomas Wills, contemporáneos a Borelli, estudian la estructura molecular y la fisiología de la contracción muscular y el movimiento. De todos modos, todo se centra aún en la inmovilidad y la fijación: los únicos gestos hasta aquí utilizados son los de las buenas costumbres, los modales correctos, la cortesía y el decoro; se trata de una pedagogía de la manera de ser estrictamente controlada (Vigarello; 2005; 18).

El primer instituto ortopédico de Europa se establece en el Cantón de Vaud, Suiza, creado por Jean-Andre Venel (1740-1791); y es el primer hospital dedicado de forma específica al tratamiento de las lesiones y deformidades esqueléticas en niños. Varios autores consideran a Venel como el primer ortopedista y padre de la ortopedia, pues su instituto sirvió como modelo para muchos otros hospitales. Venel destacó la importancia de la luz solar y diseñó varios aparatos ortopédicos en los talleres del instituto. 
Volviendo al texto que nos ocupa, Andry hace un relevamiento y categorización de las deformaciones. El papel del movimiento sigue siendo muy global, se considera que la debilidad es la causa de las deformaciones. El autor sugiere correcciones, cuidados y detalla el uso de aparatos con muy pocas movilizaciones específicas sobre los músculos, propone una nueva economía del cuerpo que descarta la rigidez del corsé e invita al individuo a moverse. Sin embargo, Andry esboza algunas incipientes orientaciones de usos musculares un poco más específicos, como en el caso de la columna muy arqueada o el de un hombro más bajo que el otro. Si bien esta visión de la ortopedia no es aún la de los movimientos localizados para una adecuada corrección, algunos de sus detalles serán retomados por la medicina posterior para ampliar su análisis y utilización. Las correcciones son por lo general sumamente lineales y simplificadas: se fijan partes, se recomienda el uso de apoyabrazos, se coloca peso en el lado necesario.

Andry renueva la pedagogía de la postura. Lo novedoso del texto reside en su especificidad: un libro centrado en la corrección de la postura de la infancia en el cual aparece la inquietud por las desviaciones y la pregunta acerca de los criterios de rectitud deseados (Vigarello; 2005; 20), se plantea la construcción de un modelo (véase imagen en pág. 40) de referencia de corrección del cuerpo. Los textos más próximos al tema se ocupaban hasta ese momento de cirugías y tratamientos para casos de mayor gravedad. Andry pone su atención en los factores que inciden en el surgimiento de las malas posturas, en su diferenciación y en la minucia de la corrección. Aun así, tal como se explicó, en la mayoría de los casos expuestos no aparece todavía el análisis profundo de la mecánica y sus encadenamientos: Andry explica, por ejemplo, la desigualdad de hombros como problema local encapsulado en sí mismo, que no lo lleva a preguntarse sobre la desviación de la columna vertebral. La terminología da cuenta en especial de la observación permanente de la actitud y normativa: el cuerpo deforme debe ser encarrilado por un proceso de restauración.

Si bien se despliega la facilitación de ejercicios, la mano del pedagogo y la utilización del mobiliario apropiado conservan aún un efecto sustancial sobre el poder correctivo. Los huesos de los niños, descriptos como muy tiernos, permiten ser modelados por el adulto. El uso del corsé en niños conserva su indicación sólo para corregir casos de mayor gravedad, casos en los que se seguirá recurriendo también a las mentoneras y cruces de hierro. La autonomía y el dinamismo del ejercicio comparten aún territorio 
sin tener un análisis que profundice su separación y diferenciación tal como ocurrirá en los siglos venideros.

Sin embargo, la práctica del fajado del recién nacido no resulta tan severamente impugnada como la utilización del corsé. Los textos relativos a la medicina infantil lo mencionan graduando su utilización y detallando la calidad y longitud de la faja así como el grado preciso de compresión. El inicio de su condena definitiva surge en la segunda mitad del siglo XVIII con la insistencia en el debilitamiento que produce y en el obstáculo que implica para el libre desarrollo del infante. La misma causa que habilitó su uso, lo denegó: las carnes tiernas que habían necesitado ser sujetadas por un corsé para no deformarse son pensadas ahora en términos de carnes tiernas sobre cuya fragilidad el uso del corsé puede ocasionar estragos y eliminar la posibilidad de crecimiento de la propia fuerza potencial que el niño puede desarrollar. La denuncia sobre el equívoco modelado que las vestimentas compresivas puede ocasionar sobre la arquitectura ósea del niño, se centra ahora en la limitación que implican para su crecimiento. Médicos y pedagogos detallan los males de la faja: hacen retroceder las clavículas, bajar los omóplatos y perjudican el funcionamiento adecuado de los órganos. Los estudios de Lavoisier refuerzan el perjuicio para los pulmones, causado por las fajas, que impiden el buen funcionamiento pulmonar. Dice Andry al respecto:

\footnotetext{
“La mayoría de los niños raquíticos no deben este triste estado sino a la mala
}

manera en que fueron fajados, es decir, a la detestable costumbre

establecida entre las nodrizas de apretar y atar a fuerza de vendas a niños

muy pequeños, como si fueran fardos que tuvieran que enviar a algún país muy lejano.

Si la situación en la que se encuentran los miembros de un niño, en

cada vuelta de venda, no es directa sino torcida, resultan inconvenientes que influyen no sólo sobre la conformación del cuerpo, sino sobre la salud y sobre la vida del niño.

La posición natural de los hombros, de los brazos y de las manos de un niño al que se mueve, es decir que se faja, la de los pies, las piernas y las rodillas, se trastoca muy a menudo porque el niño no deja de moverse y agitarse, de manera que por más atención que las nodrizas pongan en ubicar y contener esas partes correctamente, puede suceder (y sucede muy frecuentemente) que los pies se encuentren uno sobre otro, así como las piernas y las rodillas.” (Andry, LIII, 259) 
El detalle de la morfología se precisa y los nuevos procedimientos correctivos van acentuando el uso del corsé y las fajas mal colocadas como una fuente de intensa deformación. El mal fajado da lugar a deformidades que no sucederían si se dejara que la naturaleza conduzca su propia obra. Ante todo, la medicina del siglo XVIII intenta dar explicaciones, sistematizar una lógica que da cuenta de los principios y beneficios de la actitud de la eficacia mecánica e higiénica para la buena postura. El nuevo prestigio de la naturaleza vela por un porte que busca la precisión de la correcta anatomía y su funcionamiento adecuado. La pedagogía de la postura se presenta como aquello que permite ejercer un control óptimo sobre el cuerpo (Vigarello; 2005; 40). El uso del corsé obstaculiza el normal despliegue de los movimientos y entorpece a su vez el funcionamiento fisiológico óptimo. El cuerpo aprisionado en vendajes implica músculos sin fuerza ni elasticidad. La opresión de estas vestimentas va quedando ligada a la crueldad, a la imposibilidad de vivir el movimiento libre. La noción de cuerpo fajado centrada en la mera producción de formas corteses, vira lentamente hacia un cuerpo capaz de producir por sí mismo la fuerza y el vigor, las actitudes y los gestos que el implante del mundo industrial van requiriendo. Las formas del porte permiten el buen funcionamiento de los órganos Los músculos deben desarrollar ya no la forma aquietada del baile que mantenía la forma del corsé, sino una vivacidad que dé vigor a todo el cuerpo.

Los ejercicios intentan sectorizar los trabajos, pero el análisis no logra aún ser suficiente: los movimientos son globales y la investigación de su localización no llega a ser precisa.

Los nuevos movimientos son presentados bajo el rótulo de liberación de la infancia, bajo el despliegue de una norma que asegura la eficacia de la física del cuerpo: los hombros deben retroceder y el vientre desaparecer. Surge una mayor confianza en el movimiento que los niños puedan generar. El cuerpo debe experimentar su potencia. El ejercicio es planteado simultáneamente en su aspecto libre y múltiple en formas, al tiempo que se describe la imperiosa necesidad de ser vigilado por el adulto para que imponga modalidades pedagógicas muy precisas. Las nuevas intensidades de las actividades acarrean nuevas formas de rigidez, tal vez en este caso menos evidentes. Este nuevo gesto corrector delega más fuerza en el niño al tiempo que aumenta el rigor sobre él. Se pondera la reiteración del ejercicio esperando una transformación de las morfologías mediante la explotación modificada de los recursos del cuerpo. Este cuerpo de la naturaleza se va entramando sujeto a nuevos rigores que intentan perfeccionar su funcionamiento. 
La participación del médico en la vida cotidiana del hospital no fue frecuente durante el SXVII; a finales del SXVIII, en cambio, la organización médica hospitalaria se inscribe como institución examinadora, aunque la actividad médica estaba acotada a visitar determinadas instituciones y ciertos casos de gravedad. La reglamentación de la actividad de visita médica durante el siglo XVIII estipula con precisión los horarios y duración del encuentro con el paciente, asegurando así su control diario. La presencia asidua del personal médico comienza entonces a compartir el espacio ordinario con los asistentes religiosos, encargados hasta entonces de este centro de asistencia. La formación y la confrontación de conocimientos va dando cuenta de la hospitalización disciplinada reorganizando la estructura en un espacio de control, formación y permanente examen. El hospital pasa a ser, en el siglo XVIII, un lugar del cual los individuos pueden salir y no sólo un recinto a donde iban a morir.

La medicina trabaja también en pos de un rendimiento económico de la población, es decir, en pos de asegurar el potencial de trabajo de sus individuos a través de la administración de cuerpos fuertes, poniendo al cuerpo dentro de las leyes del mercado. La medicina moderna es entonces ante todo una práctica social que pone al cuerpo en el foco de una realidad política.

Foucault sostiene que en el siglo XVIII se inicia la medicina moderna. La misma que va configurando este pasaje de una teocracia a una somatocracia, es decir, una nueva economía del cuerpo. La medicina pasa a formar parte de todo un sistema histórico, económico y de poder: -surge una verdadera economía de la salud. Aparece gran cantidad de literatura sobre salud y la medicina pasa a constituir una actividad social. Surge una nueva dimensión de posibilidades médicas a la que Foucault denominará la cuestión de la biohistoria.

Poder pensar las formas que adopta la práctica médica y la elección de objetos factibles de ser medicalizados nos aproxima a una definición de enfermedad. La forma en que se utiliza la práctica médica, el saber científico, el modo de delimitación del campo de dominio y el modo de construcción de sus objetos de conocimiento deben estar enmarcados en el juego de los procesos propios de una sociedad determinada. En este caso, es en el siglo XVIII donde se desata una fuerte intervención médica y el poder médico comienza a aumentar en tanto el conocimiento y el saber científico van avalando y dando garantía a su actividad. La medicina se impone como un acto de autoridad. La salud se transforma en un objeto de 
intervención médica y la autoridad médica comienza a tomar decisiones que van más allá de la enfermedad misma, incluyendo en su tarea la organización de barrios, saneamiento, aguas, aire, etc. y una administración que incluye un meticuloso registro de datos, comparaciones y estadísticas.

Hasta mediados del siglo XVIII las ciudades francesas estaban conformadas de modo desordenado y heterogéneo. París no tenía un poder centralizado, dado que sus diferentes comunidades y corporaciones estaban bajo sus propias jurisdicciones. Recién entonces se plantea el problema de la necesidad de unificación en pos de la construcción de un cuerpo urbano homogéneo, regido por un poder centralizador, con el fin de mejorar el creciente aumento del mercado y la organización de los centros de producción. La inserción no planificada de talleres e industrias en medio de lugares de esparcimiento, la excesiva construcción de edificios, el hacinamiento de la población y las epidemias comienzan a desatar una gran preocupación y temor por la vida en las urbes. La medicalización de la ciudad genera una planificación política sanitaria que comienza a separar, a dar lugar: los cementerios son trasladados a la periferia de la ciudad al igual que los mataderos; se planifican la circulación del agua y el aire; se construyen avenidas amplias; se desarrolla el primer plan hidrográfico de París con el fin de no mezclar las aguas, etc.

La creciente preocupación por el medio ambiente y sus elementos constitutivos se va centralizando en el siglo XVIII en una medicina urbana que se expande creando comités de salubridad en las principales provincias y ciudades. El agua, el aire y la alimentación constituyen la fuente principal de las diferentes enfermedades que puede contraer un individuo, por lo que la perspectiva de la cura se focaliza en el medio ambiente. Andry devela una particular preocupación por el medio ambiente y las diferencias climáticas de la estaciones del año.

Respecto a la alimentación, Andry detalla prescripciones y restricciones muy precisas tanto para las mujeres embarazadas como para los niños que padecen ciertas deformidades. El tercer libro incluye un artículo destinado a los dedos supernumerarios donde se destaca que los niños que padecen esta deformidad suelen ser muy voraces, acostumbrados a beber y comer en exceso. La solución para esta patología implicaría darles poco alimento aunque se debe tener cuidado porque esto le puede disminuir la vida por mejorar el dedo pulgar. La influencia del alimento y las bebidas requieren también atención por parte de las embarazadas. 
La relación entre alimentación y embarazo es descripta -entre otros- en un artículo titulado antojos que detalla el color y la forma de las manchas en la piel de los bebés recién nacidos acordes al efecto de la imaginación o deseo no contentado de la madre por comer frutillas, tomar vino o leche. (Andry; LIV. 165 )

\footnotetext{
"Las mujeres embarazadas que durante su embarazo toman mucho vino y viven de alimentos de una calidad demasiado caliente, vuelven la sangre de sus hijos demasiado activa, lo cual, por la razón alegada más arriba, puede procurarles una cabeza grande; las que no beben más que agua, y sólo se nutren con alimentos de una calidad fría, vuelven la sangre de sus hijos más lenta, lo cual, por la razón contraria, puede procurarles una cabeza pequeña. Así, sobre este punto podemos decir, de alguna manera, que las mujeres encinta son como las maestras porque forman la cabeza de sus hijos. Deben entonces evitar todos los alimentos de una calidad o demasiado activa, o demasiado fría. Que se abstengan al mismo tiempo de todas las pasiones que pueden agitar la sangre, como de una vida demasiado desprovista de acción.” (Andry, LIV, p.7)
} 


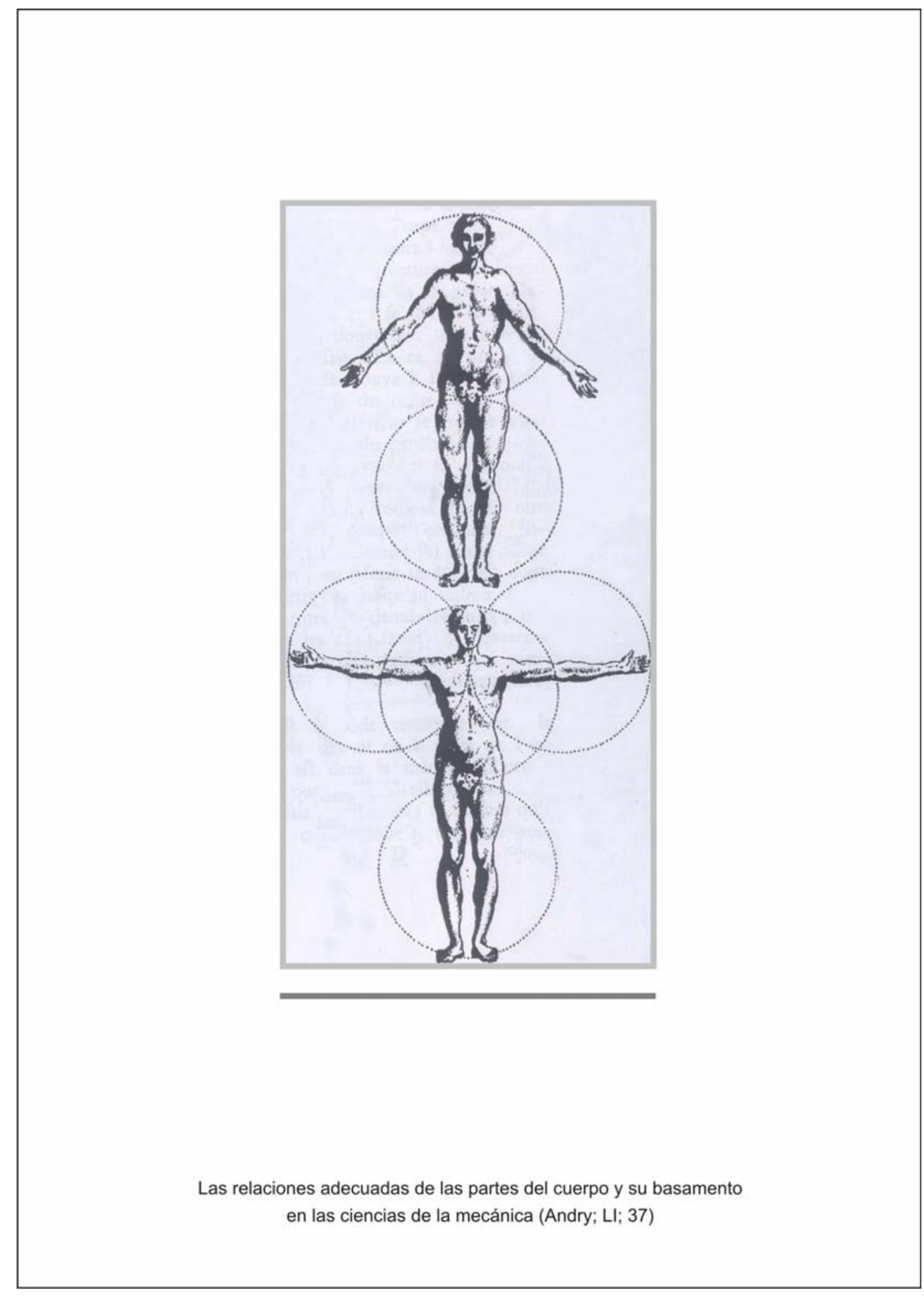




\title{
5. Nodrizas, pechos y amamante.
}

\author{
“Ninguna potencia en el cielo ni en la tierra debe dispensaros \\ de darles la leche de la Fe, de la razón, y la verdad, \\ la leche de la conciencia y la virtud”.
}

Didon, en Badinter (1991)

Los datos más antiguos de la costumbre de dar los niños a las nodrizas para que los amamanten y críen datan en Francia del siglo XIII (Badinter; 1991; 110); país que, por excelencia, parece haber sido el principal en la expansión de este hábito. Si bien en un principio esa práctica concernía con exclusividad a la aristocracia, durante el siglo XVII se extiende a la burguesía y hacia el siglo XVIII alcanza también a las clases más populares. En el París de 1780, sobre 21.000 niños que nacen menos de 1000 son criados por sus madres (Badinter; 1991; 115). Se encuentran datos similares en Lyon e incluso en pequeñas poblaciones francesas. Parte de la nobleza y de la alta burguesía llevan a las nodrizas a su hogar, pero el resto de la población envía a gran parte de los niños recién nacidos por fuera de los límites de la gran urbe. Si bien existe mucha información cuantitativa de la organización y la distribución de las clases altas, medias y trabajadoras, los datos de la población campesina parecen tener menor precisión.

El trabajo de las nodrizas no cuenta con una buena remuneración, por lo que comienzan a ocuparse de varios niños de manera simultánea sin mantener precauciones elementales para mantener su economía. Abundan los relatos de catástrofes, accidentes en los caminos y pérdidas de niños, con testimonios que denotan indiferencia y una amplia asiduidad de estas situaciones. La higiene y salud de estas mujeres no cumple las normas de cuidado que serán solicitadas en los años venideros.

La lactancia ha sido objeto de estudio y especulaciones en diferentes momentos de la historia. Para los griegos fue materia de interés no sólo en el ámbito de la medicina sino también en el de la filosofía. Aristóteles (384-322 a. c.), en Historia Animalum, consideraba que tanto la menstruación como la generación de leche en los pechos eran signos biológicos de inferioridad de las hembras en todas las especies. Se dedicó también a distinguir la calidad de la leche para determinar si era o no apta 
para la alimentación. A principios del siglo II, Sorano de Efeso, uno de los ginecólogos más conocidos de la Antigüedad, reconoció el beneficio de la utilización de la nodriza en pos de preservar la salud y juventud de la madre, siempre y cuando la selección y el control de la nodriza fuera preciso y continuo. Ofreció también extensas guías sobre los diferentes aspectos de la lactancia para las madres, los médicos y las nodrizas (Yalom; 1997; 250).

Las descripciones médicas basadas en los humores -que se remontan hasta Hipócrates- consideran la leche como una forma de la sangre menstrual. Esta teoría considera que la salud del individuo depende del equilibrio de los humores corporales: sangre, flema, bilis amarilla y atrabilis; y propone como modo de reestablecer los equilibrios -en caso de exceso de alguno de ellos- su eliminación a través de purgas, sangría, sudor o eyaculación. A su vez, la circulación de estos fluidos comprendía una conexión interna entre ellos.

En el siglo XVI, el médico francés Ambroise Paré (1509-1590) se concentra en el tema de la lactancia y las nodrizas, y advierte el modo de encontrar a una nodriza adecuada, para lo cual incluye informes que detallan incluso el color preferente de su pelo. Pero amamantar era poco decoroso: la vida social necesitaba de una madre que no podía disponerse a criar a su niño. Amamantar implicaba un gran desmedro físico, una situación ridícula y desagradable. El ideal en la corte de Luis XV seguía siendo el de un pecho sin usar, con dependencia de la nodriza para conservarse joven. Por otro lado, el complemento de la alimentación con leche de vaca recién comienza a utilizarse a mediados del siglo XVIII (en cuernos agujereados), entre otras razones por la arraigada creencia de que al succionar el bebé toma también el carácter de quien lo alimenta.

El problema de los niños abandonados se inserta en el problema de la crianza. La administración e incompetencia de las nodrizas comienza a ser observada y denunciada. Las mujeres de la ciudad recurren habitualmente a la nodriza de campo, ya sea por razones laborales -trabajos en casas de artesanos o comerciantes- o por la costumbre de evitar la ardua tarea de la crianza en caso de que sus posibilidades económicas se lo permitan. Las nodrizas más próximas a la ciudad eran las mejores remuneradas, y las más alejadas se ocupaban de los niños de familias de menores recursos. Esta distancia iba complicando el encuentro de los padres con sus hijos, así como también se complejizaba el transporte de los niños, el envío de mensajes entre las partes interesadas y el cobro por parte de las nodrizas que terminaban 
tomando varios niños a la vez. En 1769 se crea en París una Oficina de Nodrizas con el fin de resolver los inconvenientes mercantiles. La crianza de varios niños implicaba no sólo menor posibilidad de atención a cada uno sino básicamente la imposibilidad de amamantarlos adecuadamente.

Estos factores devinieron en un aumento desmedido del abandono de niños, intensificado, en los más pobres, por la falta de recursos económicos y por la falta de medidas de un Estado que los protegiera, y en los más ricos por la preocupación desmedida hacia el cuidado de las formas del cuerpo de la mujer. Las malas condiciones de transporte de los niños aumentaba también la mortalidad infantil que llegaba al $66 \%$ en el caso de las nodrizas que vivían más alejadas de los centros urbanos y un $25 \%$ en los niños al cuidado de las nodrizas más próximas a la ciudad. Donzelot $(1998 ; 19)$ se refiere a esta realidad como la mortífera industria de las nodrizas.

Los textos de época comienzan a describir la importancia de la formación de la personalidad a través del amamante. Es en la casa de la nodriza donde se adquieren los malos hábitos. El amamante por parte de las madres comienza a ser considerado como garante de la seguridad de criar niños honestos. En las conclusiones de L'orthopédie...., Andry hace referencia a esta problemática:

"No pudimos evitar declararnos contra la nación de las nodrizas ${ }^{17}$ porque son las causantes de gran parte de las deformidades físicas de los cuerpos de los niños. pero sería deseable que no les causen deformidades peores en sus mentes, sus almas y que no les hagan succionar con la leche una inclinación perversa que sería lo peor, es decir la inclinación a vengarse y mentir." (Andry; LIV; 185)

En otro artículo del libro, destinado a las deformidades en miembros, que Andry titula mano derecha izquierdizada, expone como causa de que la mano derecha esté debilitada el hecho de que las nodrizas llevan a los niños tomados de su mano derecha, dejándoles de esta manera la mano izquierda libre, que hurta así la fuerza de la mano derecha.

No existe disposición a usar preferentemente un lado que otro, por lo cual los padres, dice Andry, deben encargarse de hacer utilizar el lado correcto (el derecho) tal como

\footnotetext{
${ }^{17}$ Véase imagen en pág. 47
} 
la civilidad lo demanda. También la desgracia de las deformidades de los miembros inferiores tienen su origen mayormente en el accionar de las nodrizas, ya sea por permitirles a los niños caminar antes de tiempo o por utilizar de manera incorrecta y desmedida las fajas que colocan a los pequeños. Andry describe a las nodrizas como muy perezosas, incapaces de reacomodar las fajas en el transcurso del día, las inculpa de dejarlos estancarse en el fango, de forma opuesta a lo que un animal hace con sus cachorros. En palabras de Andry:

“...vendas, que utilizan para fajarlos, no siéndoles posible deshacer esas vendas sin mucha dificultad. Por eso vemos que la mayoría de ellas sólo mueven a los niños dos veces por día, a saber, a la mañana y a la noche. Pereza que es infinitamente perjudicial para esos pobres niños, a quienes se deja así empantanados en el fango, en vez de lavarlos con frecuencia para mantenerlos en la limpieza necesaria para su crecimiento y su salud.

Observen a los cachorros cuando están bajo el cuidado de la madre: miren qué cuidados proporciona la naturaleza entonces para impedir que toquen, aunque más no fuera un instante, todo lo que escapa a su cuerpo. Sólo el hombre es capaz, en ese estado de debilidad, de dejarse apresar tranquilamente, no digo durante horas, sino las más de las veces durantes días enteros, por la infección y la podredumbre. No terminaría si me faltara entrar en el detalle de todos los errores que se cometen en lo relativo al gobierno de los niños en la cuna. Volvamos al artículo que hemos interrumpido acerca de las piernas y de los pies." (Andry; LI, 261)

A mediados del siglo XVIII, con distintos intereses y modalidades -a veces incluso opuestos entre sí-, médicos, moralistas, filósofos y científicos rechazan con vigor la entrega de hijos a nodrizas. En nombre de la Madre Naturaleza reivindican aquello que es natural para el cuerpo humano como bueno para el cuerpo político: la salud física es la salud del Estado y los pechos femeninos son su garantía. El pecho de la nodriza se adhiere a la imagen de la corrupción y el de la propia madre es concepto de bienestar y regeneración familiar (Yalom; 1997; 132).

En 1748, el Doctor William Cadogan publica en Inglaterra Essay upon Nursing ${ }^{18}$, un llamado a que las madres acepten la obligación de amamantar, que llega también a Francia. Lejos de quedar por fuera, el padre, en el tratado, tiene la obligación de vigilar que esa actividad sea realizada como corresponde. Cadogan basa su insistencia en que la dificultad de amamantar se debe a la falta de instrucción de las

18 "Ensayo sobre la lactancia”. 
madres para hacerlo y en la incapacidad de las madres de renunciar, al menos en parte, a la belleza de sus pechos. Una madre que amamanta cumple con la familia, la población y el Estado.

Otro libro significativo es el del sueco Carl von Linneo, que publica en latín Nutríx noverca ${ }^{19}$, quien resalta la importancia de la lactancia tanto para la buena salud del niño como para la de la madre. Sin embargo, su aporte más interesante corresponde al campo de la taxonomía zoológica al acuñar el término mamífero, derivado del latín mamae, órganos secretores de la leche, para categorizar a los animales que succionan leche materna. En un texto anterior del mismo autor, Fauna suecica, la portada estaba ilustrada con una estatua de una mujer con cuatro pechos rodeada por animales y exaltada como símbolo del reino animal (veáse imagen en pág. 48). El amamante es planteado como instintivo tanto en los animales como en los humanos.

Otro ejemplo de la situación de la lactancia es la fundación, en 1788, de la organización filantrópica femenina La charité maternelle, con el fin de ayudar a las madres pobres de buena conducta bajo el compromiso fundamental de la lactancia, en una especie de control social que las damas adineradas podían ejercer sobre las mujeres de las clases pobres. Incluso el estado francés decreta en 1793 que una madre indigente no puede recibir el subsidio estatal si no está dispuesta a amamantar. La aceptación de la lactancia es una declaración política a favor del nuevo régimen y no sólo concerniente al ámbito de la vida privada.

Se reformula la maternidad, la crianza y el cuidado de los hijos como un asunto público. Se resalta la maternidad como una función natural de las mujeres (Nari; 2004; 19). Pensar la maternidad en el plano político es entenderla en tanto control de los cuerpos de las mujeres, lo cual implica a su vez un proceso de medicalización de la procreación. El registro demográfico de los nacimientos da cuenta de que la maternidad pasa a ser un asunto de orden público. La feminidad se normaliza en el lugar natural de la maternidad. La noción de naturaleza incluye en el siglo XVIII elementos que hoy separamos como pertenecientes al ámbito cultural: la maternidad es percibida como una emanación natural perteneciente al destino de las mujeres e inscripta en sus propios cuerpos. La maternidad se inscribe en la naturaleza femenina, y cualquier otro tipo de actividad, sea ésta laboral, del campo de la sexualidad o de otro uso posible del cuerpo, entorpece y amenaza la reproducción, la

19 "Madrastra nodriza". 
familia, la población. El proceso de maternalización (Nari; 2004; 101) se inscribe en las transformaciones que se vinculan al valor otorgado a la población, y en particular a la familia en la conformación de la sociedad y la política. Una dirección unívoca legitimizada por las especificidades de diferentes ámbitos: médicos, moralistas, intelectuales, higienistas y educadores.

El cuidado del niño comienza con el cuidado del cuerpo de la madre. El cuerpo femenino es la cavidad preciada y la higiene se ocupa de prepararlo incluso antes de la concepción. La valoración de la mujer -en tanto elemento de procreación y nutrición- es un objeto de políticas de Estado. El embarazo, el parto, los hijos y la crianza dan sentido al cuerpo de la mujer. El destacado lugar que ocupa el pecho femenino es solidario con el poder que enlaza el discurso de la higiene con las valoraciones del cuerpo femenino, la concepción de su funcionamiento, el trabajo y el lugar de la maternidad.

La lactancia materna se vuelve fundamental en la Revolución Francesa para Rousseau y sus seguidores, el amamante, en oposición a la práctica de las nodrizas, llegaría a producir en sí mismo una reforma y regeneración social: la de la Nación alimentando a sus ciudadanos (Yalom;1997; 18). La mujer es pensada como un ser cariñoso y sumiso por naturaleza, dotada de pechos, y el hombre como ser dotado de una mente para pensar. Para Yalom, es la primera vez en la historia que el pecho ocupa un lugar político, central, en las discusiones acerca de la población y las políticas de Estado. 


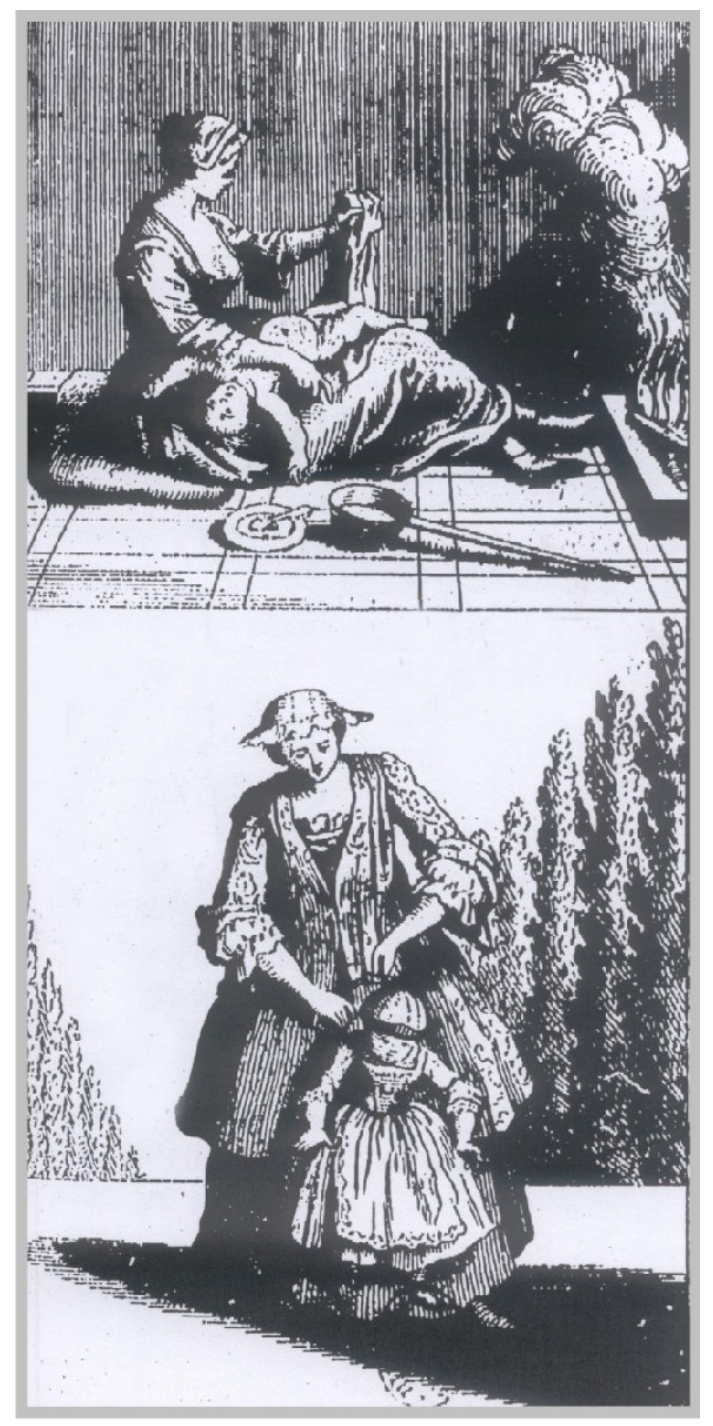

Cuidados que debe tener una nodriza con la cabeza del niño (Andry; LII;99) 


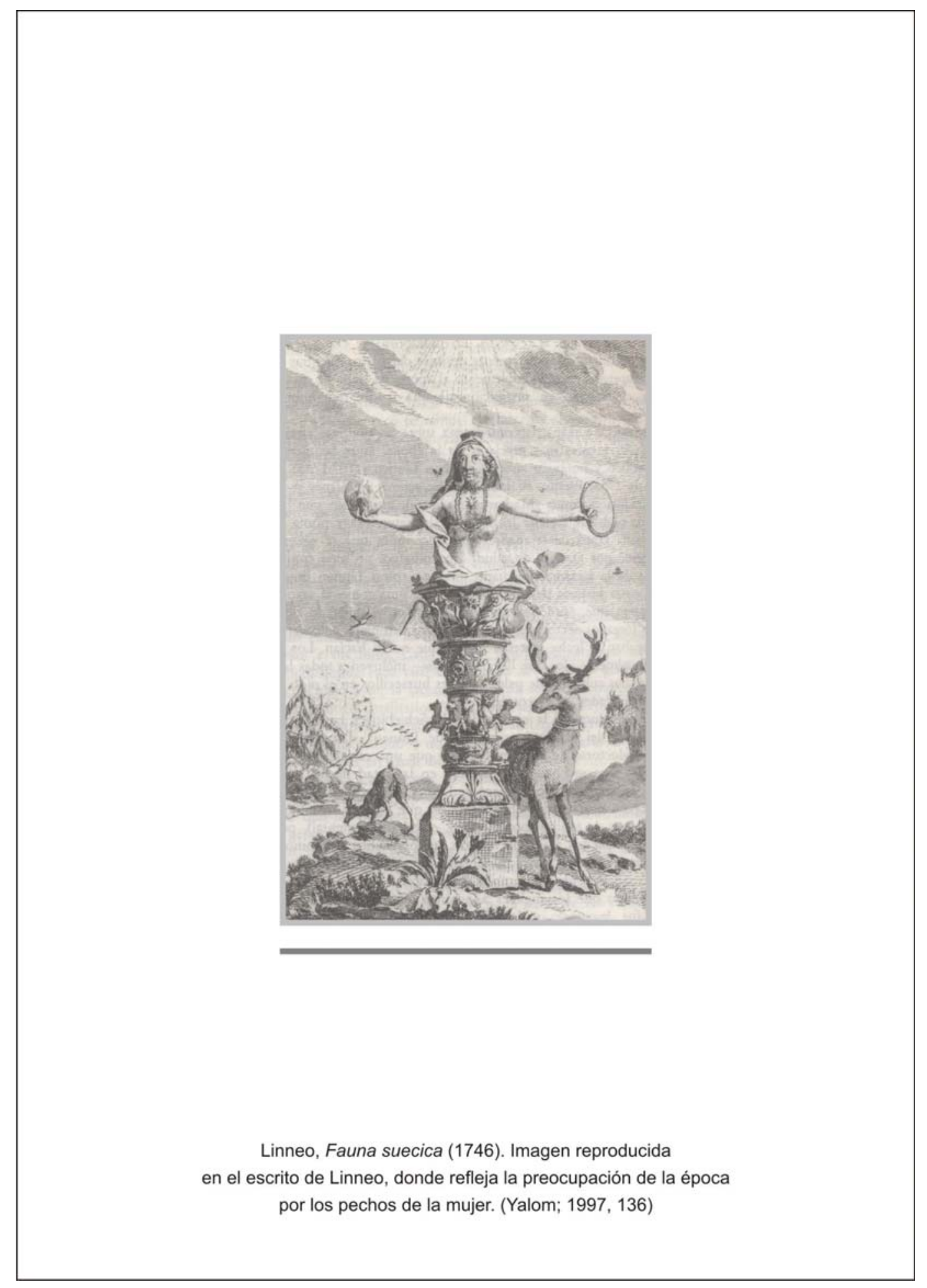




\section{Infancia y familia}

\subsection{Infancia}

"Lo mismo sucede con los sentimientos habituales del alma, un niño es educado en máximas de valor entonces los rasgos de su rostro se forman según esas máximas y se vuelven imborrables siempre y cuando esa educación sea constante y continua hasta el momento en que esos rasgos se acentúan. Los sentimientos pasajeros del alma solo dan una impresión pasajera, pero los habituales tales como los que se contraen en la buena o mala educación, buenos o malos hábitos, imprimen caracteres tan profundos que no se borran más, por más que uno se vuelva reflexivo, eso no se puede corregir porque ya se contrajo." (Andry; 16 LIV)

En el pensamiento griego, el centro de reflexión en torno a la sexualidad estuvo constituido por la relación entre los hombres jóvenes. Este foco fue virando hacia la mujer ya fuese a partir de la preocupación por la relación entre los cónyuges, por las reglas del matrimonio o la importancia de la virginidad. Es a partir de los siglos XVII y XVIII que el centro de atención gira hacia el cuerpo en sí, y en particular a la sexualidad del niño y sus relaciones con la normalidad y la salud. Nos interesa abordar en este capítulo lo particular del tratamiento de la infancia en la época que nos ocupa, tomando la diferenciación que propone Agamben cuando enuncia: "el nacimiento no produce directamente hombres, sino niños, que en todas las sociedades tienen un particular estatuto diferencial" (2003; 122).

La infancia a la que hace referencia el texto de Andry está asociada a debilidad, precariedad, inferioridad y es medida por la categoría de progreso en una temporalidad continua. Ocupa claramente un lugar cronológico; es condición para un porvenir certero. La infancia ocupa el lugar de un otro imposibilitado, disminuido pero que al mismo tiempo permite la construcción y la apuesta de producción de aquello tan deseado y esperado. La formación de la infancia, en tanto disponer de ella, ocupa en este texto la posibilidad de un futuro digno. De alguna manera adscribe a la preocupación griega de ocuparse de la buena educación en pos de una polis justa. 
Kohan $(2007$; 90) resalta ciertos elementos del tratamiento que realiza Platón respecto de la infancia en el libro II de la República, que resuenan con claridad en el modo en que podemos leer el abordaje que hace de ella Andry en su texto. En primera instancia, la importancia que se le da a la infancia desde el momento mismo en que se decide publicar el texto en pos de atenderla: la infancia es el inicio, el comienzo de una obra, el principio de su ser presente y su posibilidad de futuro. Un inicio nuevo y tierno donde el impacto de aquello que se marca se instala y perdura. Es de algún modo todo aquello que no es y que se puede hacer: lo posible, la potencialidad de aquello que se hará. La infancia es parte de lo excluido -excluido en tanto estar por fuera de la ley, la razón y el conocimiento-, es decir que su condición de inferioridad la deja por fuera del centro de la polis, al tiempo que la preocupación por educarla y administrarla es justamente la estrategia central para la transformación de la población. La infancia, a su vez, puede plantearse tanto amenazada y en peligro como amenazadora y pasible de tornarse peligrosa. Los niños quedan inscriptos, pues, en el marco de aquellos a quienes hay que educar, vigilar, corregir y controlar a lo largo de su vida para que puedan ser sujetados a un aparato de producción. Andry marca a su vez una subdivisión cronológica: en los niños menores a 3 o 4 años los músculos obedecen firmemente, por lo cual se encuentran en el tiempo favorable para reducirlos a lo que uno quiere (Andry; LII; 83), en cambio, a partir de los quince años, todo será imposible de corregir.

El texto Los anormales nos permite pensar algunas de estas cuestiones en torno a la infancia, la sexualidad y la normalidad. Foucault describe tres figuras que constituyen el ámbito de la anomalía, como antecedentes del anormal del siglo XIX: el monstruo humano, el individuo a corregir y el niño masturbador. El primero hace referencia a la ley de la sociedad y de la naturaleza: es un dominio jurídico-biológico, que se sitúa "entre la excepción de naturaleza y la infracción al derecho" (Foucault; 2000; 298). El monstruo humano encarna lo imposible y lo prohibido, e implica una dificultad en las decisiones jurídico-sociales; en particular el monstruo moral, el criminal político, que aparece a fines del siglo XVIII en este nuevo modo de economía del poder que acarrea la patologización del crimen. El individuo incorregible se sitúa entre los siglos XVII y XVIII con el surgimiento de las técnicas de domesticación del cuerpo y nos permite estudiar el recorrido hacia las "instituciones de rectificación". Justamente el individuo a corregir va a situarse entre la familia y el apoyo de ésta con las instituciones que la circundan. Ocupa ese entrecruzamiento entre la imposibilidad de ser corregido y el esmero por maximizar todo tipo de técnicas que estimulen la corrección. Será el soporte para las futuras instituciones para anormales del siglo 
XIX. El tercero, el niño masturbador, corresponde a finales del siglo XVIII e inicios del siglo XIX y hace referencia a ese espacio más próximo, entre el cuerpo del niño en su dormitorio, sus padres y el médico. Será la causa de todo tipo de patologías. Estas tres referencias dan cuenta de la formación del campo de la anomalía; si bien permanecen separadas hasta inicios del siglo XIX se reúnen luego bajo la conformación de una red regular de saber y poder bajo la figura del anormal y dan el marco a la construcción de una teoría general de la degeneración. Esto es, el ordenamiento de una compleja red institucional (entre la medicina y la justicia) que sirve a la vez de estructura de recepción para los anormales al tiempo que constituye un instrumento para la defensa de la sociedad.

Este campo de la anomalía se verá atravesado casi desde su inicio por la sexualidad, tema con el cual continuará el recorrido del texto; no como un objeto de represión, sino como aquello que estamos obligados a confesar. Este control a través del aparato de confesión-silencio, si bien varía en algunas de sus formas, perdura en el tiempo.

Este recorrido trae aparejado el surgimiento, a partir del siglo XVI, del cuerpo de deseo y placer. En palabras de Foucault "el cuerpo sensible y complejo de la concupiscencia. Eso, creo, es el correlativo de esta nueva técnica de poder (...) esta calificación del cuerpo como carne, que es al mismo tiempo una descalificación del cuerpo como carne, que es al mismo tiempo una posibilidad de discurso e investigación analítica del cuerpo; esta asignación, a la vez, de la culpa en el cuerpo y de la posibilidad de objetivar este cuerpo como carne, todo esto, es correlativo de lo que podemos llamar un nuevo procedimiento de examen" (Foucault; 2000; p.188). La carne es aquello que se confiesa.

En los siglos XVI y XVII se enfatiza la domesticación del cuerpo en tanto cuerpo útil: crecen las escuelas, los ejércitos, la distribución del cuerpo en el espacio: hay una nueva anatomía del cuerpo. Al mismo tiempo, las prácticas que acontecen en estos espacios denotan una investidura del cuerpo circunscriptas en el nivel del deseo y la decencia, esto es una fisiología moral de la carne (Foucault; 2000; 186). Esta fisiología del cuerpo encarnado coincide con los procedimientos de búsqueda de un cuerpo útil hacia finales del siglo XVIII. Se constituye entonces lo que Foucault llama "una medicina pedagógica de la 
masturbación", es decir, la masturbación pensada en términos pedagógicos y médicos, que traslada el problema del deseo al instinto, problema que será el centro de la organización de la anomalía.

El capítulo de la clase del 5 de marzo de Los anormales retoma las pautas de la confesión, de esa exacerbada discreción que va construyendo espacios, ordenando los bancos, colocando las puertas, de modo tal, que remite constantemente a los peligros de ese cuerpo de placer. Todo habla de eso que hay que acallar. Incluso los textos. A mediados del siglo XVIII se maximiza una campaña antimasturbatoria desde la literatura. Se publica material sobre la masturbación en el que prácticamente no aparece su relación con el placer, con el deseo ni incluso casi con la sexualidad. Se trata más bien de manuales de consejos muchas veces destinados a los padres, otras a los niños. Detallan las atrocidades que genera este hábito así como modos de atender o curar a los niños de este mal: recetas de medicamentos y prácticas que incluyen vendas y aparatos.

Si bien esta campaña tiene lugar en el siglo XVIII cuando se propone un cuerpo productivo aislado del cuerpo del placer, es ante todo una cruzada contra la masturbación y no contra la sexualidad; y en especial dirigida al niño y al adolescente. No se habla de la moral, se habla del cuerpo enfermo, de la patologización. Se presentan entonces dos tácticas en esta cruzada: la somatización y la desculpabilización. Foucault describe tres formas en que se encontrará este principio de somatización: la primera, como una gran fábula, que incluye una innumerable serie de síntomas de alta gravedad que irá causando; la segunda planteada por parte de los médicos más reconocidos como causa de todas las enfermedades posibles; y por último una especie de delirio hipocondríaco, una descripción detallada de la historia de las enfermedades que procuraba asociar todos los síntomas a la masturbación. Esta suerte de causas múltiples, de sintomatología polimorfa, de causalidad de toda enfermedad en cualquier momento de la vida, pone a la sexualidad, más precisamente a la masturbación, del lado de la prohibición. La historia médica focaliza la culpa de la enfermedad del lado del paciente y queda inscripto en la infancia el lugar de la responsabilidad patológica: el niño pasa a ser responsable de todas sus enfermedades, incluso durante la vejez, por causa de 
este autoerotismo infantil. Aun así, la literatura de la época no culpabiliza en forma directa al niño ya que no se encuentran causas endógenas, no se trata de la naturaleza: la responsabilidad viene de afuera, del azar y sobre todo del adulto que lo acompaña, nodrizas, gobernantas y educadores que para hacerlos dormir o en el momento del baño, incitan con o sin voluntad la excitación. Aparecen entonces nuevos responsables: los padres que no velan por el cuidado de sus hijos. Se les solicita que se ocupen de sus niños, eliminando o vigilando al personal doméstico en el intento de constituir una nueva física del espacio familiar que requiere una vigilancia meticulosa y permanente del cuerpo infantil. Se describen toda una serie de elementos destinados a impedir la masturbación de los hijos que incluyen el control de hasta los más ínfimos detalles: las sábanas, el cuarto, la cama, el cuerpo del niño. Es un pedido de proximidad del cuerpo de los padres con el cuerpo de los hijos, es la constitución de un nuevo cuerpo familiar, de un nuevo modelo familiar, del cual esta campaña antimasturbatoria es uno de sus elementos constituyentes. Este pedido a los padres no es del orden de lo moral, sino del orden de la enfermedad: parte de un saber médico que lo avala, sostiene y difunde. Un saber médico que conecta esta familia a una tecnología externa, al mismo tiempo que genera una familia medicalizada. La familia, específicamente la familia aristócrata y burguesa será la encargada de cuidar y dar aviso a esta autoridad médica para que intervenga, para que interrogue al niño ante cualquier duda y de ser necesario determine el modo de proceder: recetar medicamentos, fajas, cinturones, sustancias químicas, ataduras. Esta familia medicalizada será entonces la encargada de poner en funcionamiento el principio de normalización, será la encargada de discriminar lo normal de lo anormal, de ejercer el principio de corrección ante un cuerpo anormal.

Este control que se pide a la familia, que pone el acento de la medicina en el niño como núcleo de la célula familiar, se sitúa en un momento histórico en que la supervivencia de los niños comienza a tomar un importante interés político y económico. Los padres deben velar por sus hijos y deben encauzar sus vidas. Foucault propone pensar esta campaña dentro de una cruzada mayor, que hace referencia a la educación natural de los niños. Una educación que implica un esquema de racionalidad inmerso en reglas, enmarcado por las técnicas y saberes de médicos y educadores, que cuida tanto de la supervivencia como del desarrollo normal de los niños. Y, al mismo tiempo que el Estado pide a los padres esta marcación, les solicita que confíen parte de la instrucción de sus 
hijos a una formación que el mismo Estado supervisará. La doble demanda, dice Foucault, será que "conserven a sus hijos con vida y bien sólidos, corporalmente bien sanos, dóciles y aptos, para que nosotros podamos incorporarlos a una maquinaria cuyo control ustedes no tienen y que será el sistema educativo, de instrucción, de formación del Estado" (Ibíd.; 2000; .243). Este doble intercambio insta a los padres a cuidar de la sexualidad infantil, a evitar la masturbación de sus hijos en un límite que de todos modos no será posible y, al mismo tiempo, pide ese cuerpo infantil como prestación para el Estado.

\subsection{Familia y policía}

"Gran parte de las deformidades de los niños se deben a la negligencia de los padres que no se ocupan de revertir las malas costumbres de sus niños, dejando que se instale el mal hábito en una deformidad permanente como el caso de los niños que no cierran la boca y muestran un rasgo de imbecilidad."

(Andry; LIV, 143)

La familia, particularmente valorada durante el siglo XVIII, se repliega y estrecha sobre sí misma; y reorganiza en su alianza una nueva economía de la sexualidad. La familia en tanto célula no debe ser pensada como el lugar donde se transcribe la relación monárquica de un rey con sus súbditos con un padre todopoderoso. Más bien, la familia como célula dio lugar a la facilitación de las prácticas organizadas de natalidad, del control del sexo infantil, de la medicalización del niño y la modificación de los índices de morbilidad y mortalidad infantil.

La elección de la pareja para el matrimonio ya no queda acotada a la situación económica y social de sus miembros, sino que se amplía a la configuración de un árbol genealógico exento de enfermedades Hay que preservar a las personas dignas de alianzas matrimoniales provechosas de cualquier unión inadecuada, y evitar el desperdicio de fuerzas útiles 
Foucault y Donzelot, entre otros autores, nos permiten identificar la particularidad de la familia en la sociedad occidental en una intersección entre la política y el psiquismo individual; entre lo voluntario y lo involuntario; entre la pura reproducción del orden establecido y la posibilidad de ser pensada en tanto ser propio; entre lo social y lo económico. El desplazamiento de la familia debe considerse en el campo de las transformaciones del siglo XVIII: transformaciones en el uso de tecnologías políticas que operan sobre el cuerpo, la salud, las condiciones de la vida misma.

Donzelot plantea el crecimiento de la policía ${ }^{20}$, durante el siglo XVIII, al servicio del poder familiar. Los conventos, los prostíbulos y los hospicios en época de transición hacia el nuevo régimen familiar, concilian el interés del Estado con las familias, ocupándose de aquellos que pudieran interceder en la tranquilidad y felicidad de los nuevos protagonistas. Sin embargo la preocupación de las familias se centra en el perjuicio al honor familiar, y la del Estado en el desperdicio de esas fuerzas de producción.

La policía del siglo XVIII no sólo complementa la actividad de la justicia, sino que se entrama justamente entre el poder absoluto del monarca y las pequeñas instancias de poder en la sociedad, añadiendo una función disciplinaria: más que una institución es una técnica de gobierno propia del Estado, un dominio que requiere la intervención. La policía secunda al rey vigilando los aspectos de la población que dirigen su actividad cotidiana (trabajo, educación, etc) y la organización pública de la salud, la pobreza y de accidentes como incendios e inundaciones. La policía -en tanto administración- se entromete en la relación del hombre con su territorio y sus propiedades, con sus producciones y relaciones mercantiles por la salud. Se ocupa de la religión, la moralidad, la seguridad pública, las artes y ciencias. Se interesa por su modo cotidiano de vida, por la vida de los hombres en tanto miembros de un Estado al que intenta fortalecer. La policía da cuenta del nuevo dominio sobre el cual el poder administrativo y político puede intervenir. De Lamare (Foucault; 1996; 58) sintetiza la labor de la policía centrando su actividad en vigilar los aspectos relativos a la felicidad de los hombres, en vigilar las relaciones sociales que reglamentan la sociedad, vigilar lo viviente. Focaliza la mirada centrada en la vida misma, tanto en sus aspectos más cotidianos, indispensables y superfluos, como en los administrativos y afectivos.

\footnotetext{
${ }^{20}$ Policía: ...engloba todos los métodos de desarrollo de la calidad de la población y del poder de la Nación.(...) tiene como misión asegurar el bienestar del Estado...”en La policía de las familias, Donzelot; 1990; 10.)
} 
Ahora bien, como señalamos con anterioridad, la medicina se implanta en el seno familiar, se difunde en la clase burguesa el aspecto más doméstico de la medicina, dirigido siempre a los cuidados que los padres tienen de los hijos y desplazando a los niños de las malas influencias de los domésticos, como recalcara Andry en numerosas ocasiones.

La expansión de la literatura médica destinada a los padres sucede principalmente desde mediados del siglo XVIII hasta fines del XIX: la crianza, la educación y las normas básicas de atención médica se organizan en estas obras. Es el arte de criar niños de primera edad que se expande también a través de guías y diccionarios para el uso de las familias, que brinda normas de higiene, prácticas de ejercicios, modos adecuados de ventilación de la casa, sugerencias para el uso apropiado de cuentos y para la formación educativa en general. Este material, sin embargo, se va especificando en sentido paralelo al crecimiento de la medicina una vez avanzado el siglo XIX. La medicina atraviesa un saber en pleno cambio que revaloriza su conocimiento.

Promediando el siglo XVIII, la actividad médica se va especificando al mismo tiempo que la madre pasa a ser el ancla de resguardo del médico en la célula familiar: es ella quien ejecuta la consigna que el médico prescribe. La nueva tarea de la madre burguesa concede a la mujer un nuevo poder en la esfera doméstica que refuerza la promoción de la mujer como madre educadora y aísla a la familia como célula, alejándola de los posibles efectos de la promiscuidad social y reforzando el prejuicio doméstico. La madre es el aliado que encastra a la perfección con el médico, capaz de desarticular el oscurantismo de los domésticos sobre los niños. Se vigila la felicidad de estos pequeños seres tan frágiles. El médico proporciona un estatuto civil para la madre que promociona a la mujer como educadora y auxiliar del médico. El lugar de la mujer burguesa establece la continuidad de las tareas educativas, es el soporte de la familia y es a su vez una herramienta de difusión hacia el exterior.

Las normas higienistas de crianza, educación y salud de los hijos ofrecen, al mismo tiempo, una mayor autonomía a la mujer en el modelo patriarcal.

Se solicita la concesión de la mujer. La reprobación no es ya hacia la mujer que transgrede el orden divino, la reprobación se desplaza a la renuncia de una obligación: el abandono de la obligación de procrear, engendrar y criar a su prole. La belleza será predominantemente del ámbito de la mujer pero solo en pos de asegurar 
una descendencia fuerte y sana. La modernidad debe al cristianismo el lugar que encarna la mujer, bajo el nombre de Eva, de la figura originaria del pecado, constituida en una dialéctica sacrificial y reparadora (Lyotard; 1997; 23).

Los textos resaltan el lugar de la madre omnipresente y sutil en su mirada. Se abren y cuestionan varios frentes en la crianza: los juegos de niños se van sumergiendo en el terreno educativo, la lectura de cuentos va siendo seleccionada en su temática, los cuartos de dormir de los niños tendrán su espacio diferenciado, se aprecia el sostén de una jornada de prácticas regulares. La familia debe facilitar el máximo rendimiento de la fuerza de este niño protegido de los contactos que puedan herirlo física y moralmente. La consigna es no desviar al niño del recto camino de su desarrollo.

Hasta finales del siglo XIX la analfabetización conserva índices muy elevados, lo cual demuestra una vez más que esta renovada alianza médico-madre-Estado estaba dirigida a la clase burguesa, capaz de acceder a los textos. De todos modos, hacia el inicio del siglo XIX aumentan las asociaciones filantrópicas y religiosas que intentan restaurar la vida familiar facilitando la educación y moral de la mayor parte posible de la población.

La familia burguesa se constituye en este doble juego de estrechamiento del lugar de la servidumbre en pos de la promoción de la madre que cuida al niño bajo el aval del médico. La familia burguesa traza un cordón sanitario al tiempo que facilita al Estado un espacio de instauración de prácticas liberales y de formación de su población.

Entre el fortalecimiento de la familia burguesa y su interés por mantener su patrimonio, y la preocupación de la clase popular que pide mayor participación y cuidado por parte del Estado se activa la filantropía, en el siglo XIX , como una fórmula de intervención privada en la problemática social (Donzelot; 1998; 58), construyendo un poder positivo basado en el consejo eficaz y la norma preservativa. La filantropía promoverá un adiestramiento sanitario y educativo basado en el ahorro, con miras a la familia burguesa y a su autonomía 
El trabajo planteado en el subcapítulo 6.1. ("Infancia”) perfila la nueva economía de las relaciones intrafamiliares, que solidifica las relaciones padres-hijos al tiempo que desecha las amplias relaciones que formaban parte del antiguo hogar. Los hijos, hasta entonces al servicio de los padres, pasan a ser centro de las obligaciones y deberes que los progenitores, siguiendo las prescripciones médicas y morales, deben cuidar. Bajo el principio de la salud, la célula familiar se distribuye alrededor del cuerpo infantil. 


\section{Cuerpos bellos}

"El cuello separado de los hombros, los hombros planos y bien inclinados, el pecho amplio y elevado por delante en forma de campana. La conformación del vientre tiene que ser elevada en las mujeres y menos elevada en los hombres. (...) Un pecho bien proporcionado es uno de los grandes dones del talle... y tiene las proporciones requeridas cuando se encuentra lo suficientemente prominente, hacia delante en la parte superior, sobre todo en las mujeres; y está coronado por clavículas que no son demasiado curvadas; y no se aboveda en absoluto en la parte posterior; y no se inclina más de un lado que de otro... Un pecho prominente... traduce un hermoso efecto a la vista... Además hay que hacer que los niños, "saquen pecho" y no hay que cansarse de obligarlos a hacer este ejercicio; el movimiento que harán para cumplirlo los obligará a echar los brazos hacia atrás, lo que por consecuencia necesaria forzará la extensión de las clavículas" (Andry; 82, LI).

Los cambios en los modelos de belleza -los diferentes territorios, contornos, superficies, convergencias que se exploran para dar cuenta de qué es lo bello- no son autónomos; la belleza cambia, en palabras de Vigarello, "mucho más allá de los solos efectos de la moda: contiene las grandes dinámicas sociales, las rupturas culturales, los conflictos de género o de generación" (2005; 260).

En el siglo que nos ocupa, el orden arquitectónico de los hombres disciplinarios encuentra una de sus máximas expresiones en las figuras de la danza. Las proporciones y el estudio de la geometría alcanzan en el ballet su máxima expresión.

Con la fundación, en 1661, de la Real Academia de Música y Danza (Académie Royale de Musique et de Danse) durante el reinado de Luis XIV, suele situarse el 
origen del ballet clásico tal como hoy lo conocemos, la danza escénica académica en general y, de acuerdo a Danto (1999) el de la historia de la danza como forma de arte. La Real Academia de Música y Danza se crea con la clara intención de llevar a la danza al rango de objeto de estudio y nombrar y definir los movimientos oficiales que denoten la belleza formal

En el marco de la Academia se sistematiza un código de pasos de danza con un léxico específico compartido por bailarines, maestros y coreógrafos, con colocaciones y movimientos que pautan de forma minuciosa y precisa el accionar de las diferentes partes del cuerpo.

Se institucionaliza como forma de saber la enseñanza de la danza, lo que implica la definición de un método de enseñanza y la definición de un lenguaje que pueda ser transmitido de modo universal. Un ejemplo de este intento de normalización es la elaboración y la definición de las cinco posiciones de base de la técnica clásica, por parte de Charles Pierre de Beauchamps (maestro de danza de Luis XIV).

Durante este periodo, la institucionalización del saber mediante la creación de academias no es exclusiva del campo de la danza, es un fenómeno común a otras áreas del arte y la ciencia. Siguiendo a Arnold Hauser "la vida artística tiene en Le Brun y Boileau sus legisladores; en las Academias sus tribunales; en la persona del rey y de Colbert, sus protectores" (1994, tomo II; 119). No era posible presentar un nuevo espectáculo de danza sin que fuese aprobado por la Academia. El arte se encontraba sometido a un reglamento, a normas muy precisas; del mismo modo que cada aspecto de la vida de los súbditos estaban regulados por pautas absolutas, se ejercía sobre el artista una vigilancia permanente. El ballet estaba concebido para divertir al rey y a la corte, y para poner en escena la legitimación de su poder y su dominio en todas las esferas de lo social.

Estos elementos que se observan con tanta claridad en la danza (pero que nos sirven también para pensar la concepción de cuerpo en la modernidad) a partir del siglo XVII tienen parte de su fundamento en dos concepciones (o hechos o bases ): la concepción mecanicista de la naturaleza fundada por Galileo, con su intención de conocer matemáticamente las leyes que producen los fenómenos naturales; y las investigaciones de anatomía y fisiología basadas en la disección de cadáveres realizadas por Andrés Vesalio, William Harvey y Thomas Willis, entre otros, estudios que denotan una visión crecientemente desacralizada y autónoma de los cuerpos. 
De todo modos, este modelo de belleza basado en la geometría y las proporciones no queda circunscripto al ámbito de la danza, sino que se aplica en general a las clases altas del periodo, y responde al ideal de racionalidad que impregna tanto el conocimiento científico como la vida cotidiana: "se trata de una belleza ligada a lo etéreo, a lo extraterreno, pero a la vez una belleza altamente racionalizada, sometida a reglas y principios en la misma medida que lo son los movimientos del ballet: el cuerpo bello es `el cuerpo que experimenta las reglas de la razón”" (Vigarello; 2005; 66).

Crece el foco hacia un cuerpo que produce y consume, en el marco de una política que busca innovar los cuerpos, inventar, controlarlos de manera cada vez más precisa y puntual, al tiempo que intenta controlar a las poblaciones de manera cada vez más global. Pensar las prácticas por las que los hombres buscan transformarse a sí mismos nos permite rescatar ciertas concepciones y ciertos valores estéticos que dan a su vida.

Respecto al uso del corsé, la crítica pasa a ser tanto anatómica como estética. Un tronco demasiado apretado pierde sus funciones, por lo tanto pierde su belleza. El corsé y las fajaduras en infantes son los primeros en ser descalificados, la disponibilidad de movimiento en la infancia comenzará a explorar un nuevo terreno. El corsé y las fajaduras en infantes son los primeros en ser descalificados: la disponibilidad de movimiento en la infancia comenzará a explorar un nuevo terreno. El corsé utilizado por las adolescentes consiste en fibras de ballena unidas por cordones que rodean y enmarcan el tronco con el objetivo de reducir el talle. Ajusta principalmente el pecho y el abdomen, la presión suele ser tal que conlleva con el tiempo la aparición de enfermedades. Los cuerpos de los ricos, plantea Donzelot, se veían menos saludables que los cuerpos de los campesinos más humildes, en parte por la actividad física que el campo requería y en parte por las dificultades que ocasionaban en el terreno de la salud los corsés y artificios del vestido y otras exigencias estéticas a las que suscribían las clases más ricas. Bajo la imagen de la rigidez, la eliminación gradual del corsé descarta una codificación del refinamiento clásico. Sin embargo el corsé para mujeres deberá saltear primero un paso intermedio: la utilización del corsé de fieltro menos ajustado vendido por un sastre de Reims (Vigarello, 2004; 108). De todos modos, el corsé de la dama de la corte del siglo XVI va sumando críticas: el encabalgamiento de las costillas ajustaba por demás su estómago y le impedía una buena alimentación, la delgadez extrema y su 
consecuente deformidad anatómica implicaron un desorden fisiológico que llevaba incluso a la muerte.

Junto con la preocupación por la salud, son también los nuevos ideales de belleza los que propician un viraje desde la estática hacia el campo de la actividad, hacia la exploración de las funciones más que a la rigidez de las partes, hacia el movimiento y a la posibilidad del propio cuerpo de organizar y vitalizar sus funciones.

Las caminatas comienzan lentamente a ser indicadas para lograr reconstruir el porte y otorgar flexibilidad, las mujeres las practican con vestido corto y un largo bastón. Lentamente se va abriendo paso a la idea de asociar el embellecimiento con el fortalecimiento muscular.

En paralelo a la preocupación por sacar el corsé, a mediados del siglo XVIII, la estética de las formas comienza a dar lugar al testimonio de los sentidos (Vigarello; 2004; 93). Las descripciones de los textos, incluso aquellos del orden de la medicina, comienzan a otorgar prioridad al juicio de lo sensible, esbozando una fragmentación (o ruptura) entre las referencias colectivas y la búsqueda personalizada de la belleza. Lo bello se irá inscribiendo en lo humano, más específicamente en aquello ligado a los cuerpos que denoten el fortalecimiento de la salud.

La pintura comienza a develar movimiento, a captar el momento, a registrar lo fugaz. La técnica del pastel, ampliamente utilizada, refuerza en su trazo lo instantáneo: las espaldas semi descubiertas, los pies descalzos, los movimientos corporales adquieren otra densidad; se reflejan denotando un tiempo, el tiempo en el que transcurre la escena. Los fisonomistas comienzan a impregnar la belleza con su propia sensibilidad: en la pintura, por ejemplo, las proporciones de los cuerpos deslizarán sus primeros trazos a gusto del artista y ya no sólo respetando las relaciones prefijadas.

La sensibilidad y el sentimiento comienzan a invadir el universo de la belleza corporal y sus posibles expresiones. Andry refuerza la importancia de inspirarles sentimientos nobles a los niños, ya que los sentimientos del alma dejan su impronta en la expresión; y es justamente en la expresión donde se observa el encanto o desencanto de una persona:

"Resulta de todo esto que los padres son como los maestros con la fisonomía de 
sus hijos, puesto que la fisonomía depende de los sentimientos del alma, que los sentimientos del alma dependen de la educación, y que la educación depende de los padres. Un padre y una madre no pueden volver regulares los rasgos del rostro de un niño si no lo son. Pero pueden formar la mente y el corazón del niño, y formándole la mente y el corazón le formarán el aspecto del rostro.

Cuando los niños hacen o dicen algo bueno, apruébenlos mediante alguna palabra elogiosa. La aprobación les eleva el alma, y si se es cuidadoso con eso, se verá que su rostro, cuando aprobamos lo que han dicho o hecho, adquiere rasgos nobles. Pero con ese pretexto no vayan a hacer a sus hijos elogios exagerados. Dichos elogios los volverían orgullosos, quizá incluso insolentes, y en consecuenca imprimirían sobre sus rostros rasgos de orgullo y de insolencia que los harían odiosos a los ojos de la sociedad. Estas reflexiones bastan para excitar la vigilancia de los padres sobre otros varios puntos que suprimo."

(Andry, 28- 29LIV)

El rostro es citado como el molde en que se reflejan los sentimientos del alma (Ibíd.; 25 LIV); refleja, como un papel, los rastros de sus pliegues, y son justamente los padres los mâitres (Ibíd.; 18 LIV), amos y maestros, los encargados de formar el aire y aspecto del rostro del niño. Los problemas y la tristeza pliegan el rostro del niño y es deber de los padres ablandarlo mediante la alegría y la calma. Cada aspecto del rostro, de la expresión, debe ser considerado y cuidado. Las mejillas deben dar un aspecto saludable, para lo cual se debe cuidar que el niño no tome el mal hábito de inflarlas por de más para evitar el aspecto de rudeza y cólera. Tampoco los padres deben permitir que los adultos besen y aprieten las mejillas de sus niños ya que puede producir descamaciones y contagios. En el detalle del modelo óptimo de oreja, Andry recalca la importancia de esconder las orejas horriblemente deformadas. Dice el autor al respecto:

"Ostentar lo que se puede hurtar a la vista no es tan grave, pero mostrarlo es muy poco adecuado." (130 LIV)

Los textos pretenden categorizar los nuevos principios de lo bello, principios esta vez centrados en el hombre. Los detalles de belleza no quedan ya reducidos al cuerpo estático sino en el detalle y la elegancia del cuerpo en acción, en la relación y convergencia entre las partes. Así lo demuestran también la gran cantidad de ilustraciones que revalorizan el accionar de los oficios dando un sentido estético y 
una mirada emotiva a la actividad práctica de un artesano, un carpintero, un hombre colocando tejas.

Resuena también en las artes la nueva situación de la mujer-madre, y su imagen anatómica comienza a concentrarse en sus caderas, en el albergue de los órganos que darán respuesta a su función de gestación. Una concepción de la forma terminantemente opuesta en la relación entre caderas y pecho del hombre y la mujer: forma romboidal para la mujer y trapezoidal para el hombre. La visión funcional va describiendo y estampando imágenes del andar de la mujer: la amplitud de las caderas, la inclinación del fémur, un andar vacilante, lento y bello. La literatura detalla los modos de caminar de la mujer revelando allí mismo su mundo de sensaciones.

Andry indica modos para la correcta educación de la marcha: el adulto debe estar atento a no dar pasos largos cuando lleva a un niño a caminar, para acostumbrarlo a una marcha tranquila y evitarle la fatiga o incluso trastornos respiratorios. Tampoco debe sostener al niño en sus primeros pasos, pues le daría mala gracia en el andar y haría que el niño fuese mirado en el mundo con desprecio (Ibíd.; 274, LII). Es importante intentar que los niños caminen con gracia, ya que sino serán mirados como tontos (Ibíd.; 275, LII). Para ello puede ser de gran utilidad pagarle a un buen maestro de baile, sin reparar en el gasto, ya que será también de gran importancia bailar de modo agradable una danza de salón. La gente de calidad siempre tiene un "buen andar" (Ibid.; 279, LII).

La importancia de la lactancia también queda plasmada en el arte. Los cuadros comienzan a mostrar imágenes de mujeres amamantando e imágenes de escenas familiares íntimas. Un grabado de 1785 de Auguste Claude Le Grand, titulado Jean Jacques Rousseau ou l'Homme de la nature (véase imagen en pág. 69), lleva por epígrafe "Él restituyó a las mujeres sus obligaciones y a los niños la felicidad" y muestra en el centro la imagen de una madre de mirada tierna amamantando bajo la sombra de un árbol. También son conocidos los cuencos de porcelana que María Antonieta mandó a modelar con la forma de sus propios pechos en la corte de Luis XVI (véase imagen en pág. 70). La nueva República francesa es representada más de una vez por mujeres con los pechos descubiertos que proveen abundante alimento a la población (véase imagen en pág. 71). Diderot ${ }^{21}$ en la Enciclopedia sugiere a los aprendices liberarse de los modelos preestablecidos para captar el

\footnotetext{
${ }^{21}$ Diderot (1713-1784), escritor y filósofo, editor de la primera Enciclopedia francesa.
} 
verdadero movimiento de las acciones de la vida. Esta invitación mantiene aún fuertes modos intuitivos y dista de ser un análisis detallado y profundo. Se abandona progresivamente el dibujo preconstruido del rostro para captar el rastro inmediato, y en cuanto a las temáticas, se abandonan las imágenes religiosas al mismo tiempo que aumentan los retratos personales post mortem que intentan conquistar lo particular de los rasgos del individuo.

La belleza y buena proporción facial cobra un valor diferencial: la rectitud de la frente, la caída de la nariz, la mandíbula y los labios hacen de la fluidez vertical un valor estético. La descripción del cráneo entra en comparación con los animales abriendo un abanico que va del mono al hombre europeo, pasando en el interin por el hombre negro (Vigarello; 2004; 104).

Los cuidados se extienden también al cabello; prueba de su importancia es que Luis XVI crea, en 1777, 600 cargos de peinadores. También Andry dedica cuatro artículos al cabello y sus deformidades, señalando que es fundamental para acentuar una buena cara (Andry; 9, LIV). Detalla los problemas de la sarna en el cuero cabelludo que roe a los cabellos como el óxido al hierro, describe la importancia de un buen cepillado para evitar costras y escamas y recomienda recurrir a remedios de uso interno y externo para un buen tratamiento. Esto incluye purgas, cremas, lavados con orina fresca de la persona que padece la deformidad (Ibid.; 12, LIV) y la utilización de mirna en polvo. El color del pelo denota también señal de deformidad y está directamente relacionado con los nutrientes que la madre encinta haya ingerido y con la alimentación del individuo afectado; las afecciones del corazón y la tristeza generan canas prematuras, y los cabellos oscuros son habituales en personas soñadoras e irritables (de peor temperamento con una bilis oscura) (Ibid.; 18, LIV). El cabello castaño sería el color acorde a un buen temperamento.

La cosmetología se extiende a todo el cuerpo. Los cosméticos deben adaptarse a cada persona. La medicina comienza a dar aval a los productos de maquillaje y los productores de cosméticos se dirigen a la Academia de Ciencias. El comercio de maquillaje se multiplica y jerarquiza, y sus diferentes calidades señalan un rango social. Los matices de tonalidades aparecen en los productos refinados en un gesto hacia lo particular que atestigua lo selectivo.

Hacia la década de 1770 los jarabes tradicionales para los humores serán reemplazados por tónicos fortalecedores de nervios. La atención vira hacia la tensión 
de las fibras como señal de belleza y salud, lo que invita a prácticas de trabajo físico, marchas y usos específicos de baños en aguas de belleza. Los elementos atmosféricos son considerados vitales en la estimulación del cuidado: el aire frío por sus efectos de endurecimiento de las fibras y el agua -principal instrumento de tocador a fines de siglo- por su efecto de limpieza y sus propiedades como tónico excitante. Proliferan los tratados destinados a detallar los usos adecuados del agua como fuente de higiene y belleza, una práctica que resulta novedosa considerando la pequeña estructura que las casas tenían para lavabos y bañeras. El interés por las funciones físicas busca focalizar la atención en la actitud, en la medición de las propias fuerzas. La funcionalidad hace referencia a la combinación de las tensiones en juego.

En la década de 1780 aparecen los primeros vestidos sin entallar, de telas livianas, transparentes y con pliegues amplios que se oponen a la rigidez del antiguo corsé. Los hombres comienzan a vestir calzones jacobinos en señal de igualdad (Yalom; 1997; 147). Todas estas costumbres, claro está, concentran su atención en la clase burguesa. Al respecto, Andry se expide sin sutilezas: él no escribe para la gente de campo ni para los pobres. A estos últimos los considera portadores de malas manos, muchas veces con venas por demás salientes, como suele suceder también en las de los obreros:

"La belleza de las manos es señal de calidad de la persona: podemos encontrar mujeres pobres de bellos ojos o de bella boca, pero es muy raro que las encontremos con manos que conserven la belleza."

(Andry; 169, LIII)

La negligencia y los malos hábitos de la gente de campo son descriptas como muestra de la deformidad, tal como la costumbre de andar con las piernas chuecas. Andry insinúa que en este sector de la población - que equipara en este aspecto a personas de otras culturas- o bien no tienen noción de belleza o bien tienen sobre ella una noción errónea.

Las deformidades del cuerpo que describe Andry van acompañadas, muchas de las veces, de valoraciones relativas al gusto, a lo agradable, a lo estéticamente correcto, denotando la carga moral que se deposita en la belleza: 
"La sarna en las manos, tanto en hombres como en mujeres, en los brazos y las manos femeninas (cuando ellas llevan los brazos descubiertos) es una deformidad muy considerable, de lo más desagradable a la vista."

(Ibíd.; 219, LIII)

La cuestión del gusto, fundamental en el siglo XVIII, es identificada por Danto (2005; 113) junto con la razón, como atributos definitorios de la llustración. La belleza se vincula indisolublemente al gusto, y el gusto cultivado es la marca del refinamiento estético. Se plantea una educación estética con normas susceptibles de ser aprendidas durante un tiempo acotado, de manera tal que el discípulo pueda luego discernir cuándo algo es bello, de acuerdo al buen gusto adquirido.

La minucia del detalle es infinita. El artículo dedicado al color de la uña describe la uña bella que conserva el color rosa pálido: cualquier otro color implica defectuosidad. Si son muy pálidas dan cuenta de una persona moribunda, si son muy rojas, de una persona demasiado ruda (Andry; 241, LIII). Para la uña será fundamental el color de la carne que se encuentra debajo de ella y de la presión que ella misma ejerce sobre la piel. Los dedos bellos con uñas de buen color son señal de perfección.

La relación lineal y directa entre la forma del cuerpo y las características del ser -los rasgos físicos como expresión de la personalidad del individuo- se retoma en el capítulo de la cabeza: la cabeza muy grande por esfuerzos circulatorios puede provocar una mente menos viva (tal como cita el refrán cabeza grande, poco sentido) (Ibíd.; 6,L IV) o la cabeza muy pequeña que es señal de poco esfuerzo. Incluso Andry cita la asociación de la deformidad de labios gruesos con rasgos de poca inteligencia, lo cual para él es sólo un prejuicio público, pero como está instalado considera que es de alta importancia que los padres se ocupen de corregir semejante defectuosidad en sus niños (Ibíd.; 141, LIV) .

El modo de relacionarse con la deformidad ya no es el de la Edad Media; lo más sobresaliente en el siglo XVIII es el inicio de una pedagogía de las formas que el cuerpo debe acatar. La preocupación por lograr la buena forma es de suma importancia ya que ésta implica belleza y la belleza conlleva en sí la promesa de la felicidad. 
Podemos pensar en el surgimiento de una estética de lo singular dentro del marco de una belleza ideal: un movimiento apegado a la belleza genérica dotada de equilibrio, que resalta a su vez los indicios particulares de la belleza singular. La producción de cuerpos bellos en un principio se revela como la educación, el saber y las buenas costumbres propias de la clase burguesa. La preocupación por el debilitamiento de las carnes y la pérdida de las agraciadas proporciones con el transcurrir del tiempo denotan la imagen de la degeneración. Esta problemática hace referencia a los avances y retrocesos del progreso y al crecimiento de la ciudad, al tiempo que la clase burguesa reclama al Estado la responsabilidad de que se ocupe de la población como recurso y la imperiosa necesidad de que se ocupe de la higiene y el bienestar. Vigarello $(2004,133)$ resalta, en las últimas décadas del siglo que nos ocupa, un cambio significativo respecto a la conservación del modelo físico: la promoción de un modelo más activo y vital donde el movimiento y la robustez de los cuerpos son señales de salud e higiene. Una preocupación por la belleza y la anatomía, cuya estética deviene en inquietud del gobierno.

Se diseña y formula con precisión una estética de la conformación Se unifica la moda de la vestimenta con el criterio de las formas que el cuerpo debe adoptar. Las prácticas de corrección parecen quedar envueltas en algunos tramos del texto, más en una actitud estética que en un procedimiento de salud. La rectitud es ante todo señal de elegancia y la ortopedia permite justamente la restitución de esas formas adecuadas y la prevención para lograr la apariencia deseada. Ya no se trata de una estética del cuerpo para un cuadro estático y aquietado, sino de un despliegue del movimiento. La crítica a las maneras bellas de los siglos anteriores se enfatiza y las categorías de los nuevos movimientos proponen mayor diversidad. 


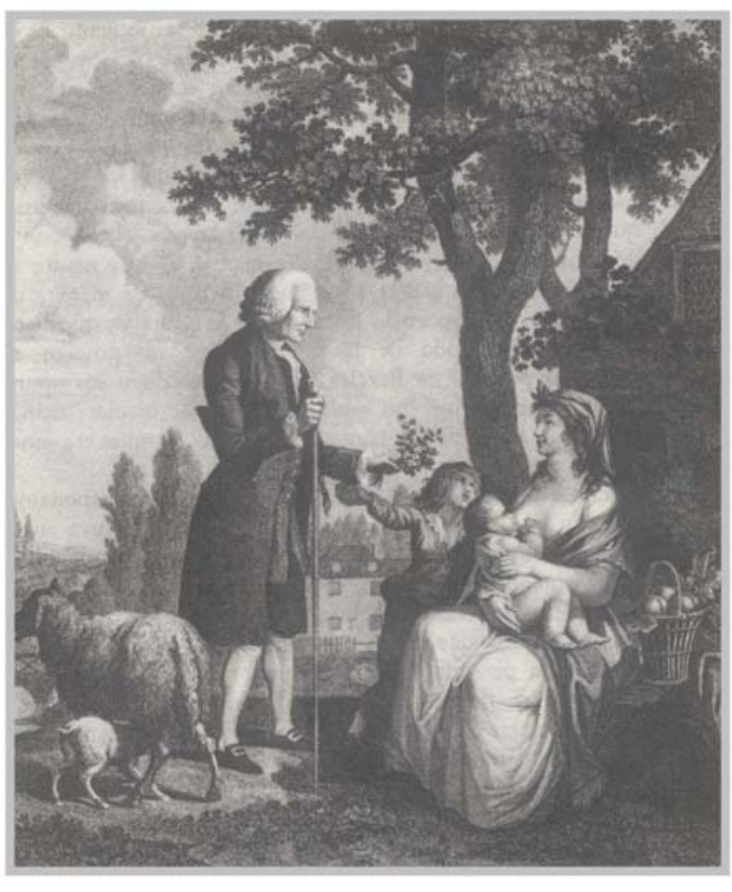

Auguste Claude Le Grand, Jean Jacques Rousseau ou I'Homme de la Nature. Grabado 1785. La obra incluye un grabado que afirma: El restituyó a las mujeres sus obligaciones y a los niños la felicidad. (Yalom; 1997; 138) 


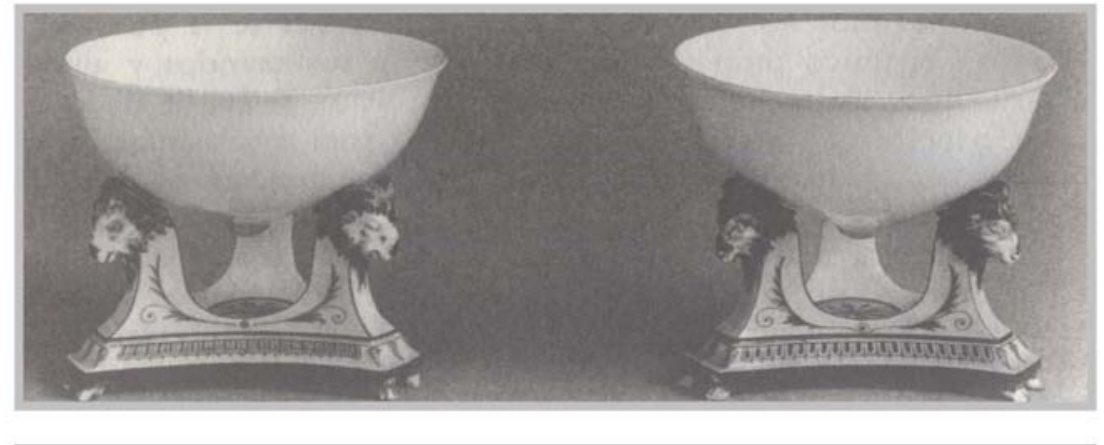

Cuencos de porcelana de la granja de Rambouillet, fabricados en Sévres para maria Antonieta. La leyenda cuenta que se han fabricado con el molde del pecho de maria Antonieta. (Yalom; 1997; 140) 


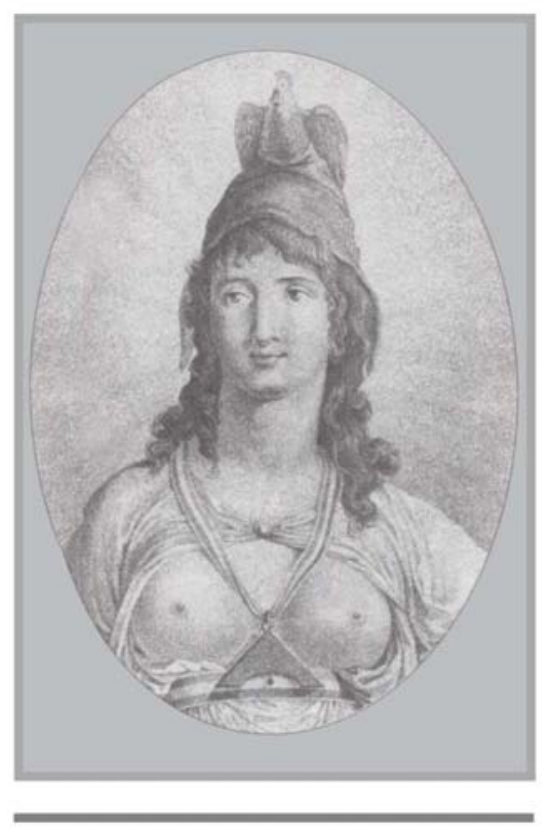

La France Republicane, ouvrant son sein á tous ses citoyens, 1790.

Imagen de la Nueva República francesa representada con frecuencia como una mujer que abre su pecho a todos sus ciudadanos. (Yalom; 1997; 145) 


\title{
8. Conclusiones
}

\author{
"El modelado del cuerpo da lugar a un conocimiento del \\ individuo, el aprendizaje de las técnicas induce modos de \\ comportamiento y la adquisición de aptitudes se entrecruza \\ con la fijación de relaciones de poder (...)".
}

(Foucault; 1989, 301)

Este estudio del modelo del funcionamiento histórico de la corrección del cuerpo infantil entendido como parte de un sistema histórico en relación a los vínculos entre la medicina, la sexualidad, la familia y el Estado nos permite pensar no tanto en términos de su aceptación o rechazo sino en cuanto modelo que se puede rectificar, aplicar o modificar en nuestros días. Una investigación histórica crítica, particular en tanto que se refiere a la situación concreta de la aparición del primer texto de ortopedia infantil, pero general en tanto que al plantear la problematización de los diferentes ejes que la atraviesan, da cuenta de la constitución misma de nuestro modo de abordar el cuerpo infantil.

Transformar la mera crítica de la limitación en una crítica práctica centrada en el modo de aquello posible, nos permite trabajar en los espacios que constituyen una frontera (entre el Estado y el individuo, entre el médico y la familia, entre el Estado y la medicina, etc.), en ese intersticio donde tiene lugar esta familia que vela por el cuerpo de sus niños, sin la intención de dar una validez universal al reconocimiento de determinadas estructuras sino entendiendo la investigación histórica de ciertos acontecimientos que determinaron en parte el modo de constituirnos, pensarnos y actuar. Es la articulación de ciertos discursos, actos y acontecimientos históricos que recorta en la contingencia esto que hace factible la posibilidad de ser de determinado cuerpo infantil.

Como hemos expuesto, en el siglo XVIII una de las funciones fundamentales del Estado es la de garantizar la salud de sus ciudadanos, asegurando su fuerza física, su capacidad de producción y trabajo: la salud es objeto de una verdadera lucha política. Es en este marco donde el rescate y el cuidado del cuerpo infantil quedan inscriptos en parte dentro de un problema económico y político de la población que está pendiente de medir cada factor que altere el crecimiento y la fuerza vital: se 
cuantifican la tasa de natalidad, los tipos de matrimonio, los nacimientos legítimos e ilegítimos, la frecuencia de las relaciones sexuales.

En el ámbito de la clase burguesa se otorga al cuerpo el lugar de un cuerpo a ser cuidado, cultivado y protegido. Se constituye un cuerpo de clase que resalta la higiene y la salud del organismo en pos de la descendencia. La clase burguesa busca, en términos de Foucault (2002; 153), darse un cuerpo y una sexualidad. El cuerpo no queda subordinado a un aspecto económico del vigor de la población, sino que resalta su dimensión más física, tal como lo atestigua la gran cantidad de obras publicadas hacia fines de siglo XVIII centradas en la higiene del cuerpo, el arte de la longevidad, las instrucciones para desencadenar una buena descendencia. Esta diferenciación de cuerpo pasa a ser una forma de clase. Se hace de la corrección un objeto de trabajo aplicado inicialmente por la clase burguesa para sí misma y que en una segunda instancia se aplica a las clases populares. El ejercicio físico con sus formas rudimentarias presentadas por Andry -que adquirirá otras más precisas durante el siglo XIX- es testigo de la preocupación por la eficacia y la rentabilidad de los cuerpos.

La operación de Foucault va a ser justamente la recuperación de la corporalidad. La política es siempre política del cuerpo, el objetivo de la política es el cuerpo, y situar ese cuerpo en un territorio es la base de la disciplina. Disciplina es organizar políticamente el espacio. Es una técnica de poder que tiene por objeto los cuerpos individuales y cuya especificidad consiste en tratar de fabricar un cuerpo que sea políticamente dócil y económicamente productivo. Quiere fabricar un cuerpo que es productivo porque es dócil. La disciplina es una forma de poder sobre el individuo, que estudia la normalidad y la anormalidad y se remite al origen del cristianismo. En el siglo XVIII el Estado estatiza las técnicas disciplinarias y las expande por la sociedad de manera no ya ritual como en el feudalismo, sino continua, con mecanismos permanentes de vigilancia y control. Se elabora una nueva economía de los mecanismos de poder, que busca disminuir los costos (de los mecanismos) económicos y políticos y aumentar la producción del poder. La idea de que el hombre tiene que ser de determinada manera es la estrategia para convertirnos en sujetos, en hombres normales: obedientes, productivos, reproductivos, consumidores, contractuales. La subjetividad queda entonces planteada como un problema político, la subjetividad es un efecto de las políticas de los cuerpos. El objeto del poder es siempre el cuerpo y no la ideología: donde hay poder hay corporalidad. Uno de los propósitos de la disciplina es el de fijar la población en espacios determinados en pos 
de la acumulación de población y de la producción de capital: la escuela, la milicia, el hospital y principalmente la familia constituyen núcleos de anclaje para la población, cuyo aumento demográfico debe delimitarse en un lugar ajustado. Las relaciones entre los miembros de la familia -en particular la relación de padres con hijosabsorbe desde la época clásica modalidades y formatos externos, pertenecientes al ámbito escolar, militar y médico que hacen de la familia el lugar de excelencia para la cuestión disciplinaria de lo normal.

El cuadro de referencia de la corrección de la postura del cuerpo infantil es la familia y como extensión de ésta, las instituciones pedagógicas. Estas propuestas y transformaciones se enmarcan en un proceso de educación natural que determinan el lugar de los padres como educadores de sus hijos y el reconocimiento de que esta relación debe estar atravesada por la racionalidad y disciplina de la pedagogía y la medicina. Ahora bien, estas deformaciones (medidas en rangos de mayor y menor complejidad) del cuerpo infantil sobre las que se llama a trabajar no constituyen un caso excepcional sino que paradójicamente constituyen casos habituales, es decir que se trata de un caso regular en su propia irregularidad. Al mismo tiempo se plantea una insistencia en corregir lo que parece imposible de llevar hacia esa perfección tan anhelada: aquello incorregible que hay que corregir. La dirección del texto de Andry es justamente hacia un cuerpo ideal, sin deformaciones, es el ejemplo, el paradigma entendido como un modelo (que es una realidad justamente imposible de alcanzar). Se puede leer la deformidad no como excepción, sino que ese ideal que Andry plantea es el que ocupa el lugar de la excepción, o más aún de lo inalcanzable. La conciencia moderna va delimitando lo irregular, lo desviado al tiempo que constituye la distinción de lo normal y lo patológico en un concepto fundamental de su organización.

En el siglo XVIII el poder de la norma aparece a través de las disciplinas, una norma que tiende a homogeneizar en oposición a la ley que tiende a separar. Hacia fines de la época clásica la normalización es uno de los grandes instrumentos de poder. La norma busca la homogenización al tiempo que observa, clasifica y jerarquiza individualizando las desviaciones y marcando las diferencias. La norma se establece en la organización de la salud, en los hospitales en tanto institución que examina, en la regularización de la producción industrial y en la estandarización de la educación, particularmente bajo la escuela normal. 
Se especifican actos bajo una disposición de categorías generales. En lo particular del cuerpo infantil, se señalan las desviaciones jerarquizando las aptitudes, cualidades y competencias, prescribiendo el modo en que deben corregirse sus defectos para que ese cuerpo pueda progresar por medio de una presión constante y permanente que permite acomodar todos los cuerpos bajo un mismo modelo.

Se administra la necesidad del cuerpo corregido y se administra su utilidad, al tiempo que se resalta el rumbo hacia la máxima eficacia y perfección posible: “...un modo específico de sujeción ha podido dar nacimiento al hombre como objeto de saber para un discurso con estatuto científico" (Foucault; 1989; 31). Las normas que se aplican sobre la pedagogía correctora se insertan como certezas indiscutidas, en el entramado de un poder que produce realidad y ámbitos de verdad (Foucault; 1989; 198). La obligación de amamantar tiene también su asidero justificable en la inscripción de un saber científico: atrapada en juicios de normalidad, anticipa el porvenir de los individuos integrándose de manera directa en su formación. Una forma que ajusta el modelado de un tono cada vez más anónimo. Una norma que se hace más penetrante y más interiorizada.

Estos modelos son solidarios con el despliegue de las ciencias, con los saberes, las referencias y las técnicas que hacen del cuerpo su lugar de experimentación. Ejemplo de esto es el corsé del siglo XVII bajo la perspectiva maquinal que se centra en los elementos del conjunto mecánico sobre el cual es factible ejercer influencias de ajuste bajo el rigor de una geometría normativa. La fijación del corsé en el siglo XVII aparece como la dominación de las pasiones y el desborde mediante un elemento material: una faja o un corsé que contienen al cuerpo del niño. Antes del XVIII la crítica al corsé es imprecisa y aislada, la denuncia de su uso se acentuará recién en la década de 1740. La fijación postural, en el SXVIII, queda imbricada en el cuidado y desarrollo muscular hacia un porte óptimo. El corsé preventivo del XVII, utilizado por las mujeres nobles, encierra en apariencia y con elegancia el furor de las pasiones bajo el manto de la elegancia y la compostura de los buenos modales. Un dominio similar al que ejerce el adulto sobre el cuerpo del niño a quien se lo hablita para el movimiento al tiempo que se lo restringe y por quien se teme y desconfía de sus impulsos. La faja materializa y encarna la sujeción del cuerpo, pero su abandono no implica, como hemos podido ver, el abandono de reglas que organizan un cuerpo: se trata de pensar estos nuevos discursos liberadores en tanto nuevos modos de establecer otras formas posibles de sujeción y control. 
El poder no es entonces concebido en tanto represión, sino en tanto pronunciamiento de una regla que organiza, mediante el lenguaje y la puesta en acto de un discurso que habla, crea y transforma; no es un poder represivo, sino promotor de una nueva individualidad. Esto implica dejar de pensar en un individuo pasivo en tanto receptor de un poder externo, para plantear un individuo al mismo tiempo receptor y emisor de poder. El poder para Foucault es aquel que se ejerce sobre los hombres libres. No es planteado en términos exclusivamente concernientes al Estado o las instituciones, sino a la red de relaciones de poder y saber y el entretejido o entramado que implican.

Foucault plantea un nuevo funcionamiento de los procedimientos de poder del siglo XVIII centrados en la técnica, la normalización y el control -en oposición al derecho a la ley y el castigo- en niveles que incluyen pero a su vez exceden al Estado y sus instituciones.

Observar de cerca el texto de Andry en tanto material histórico, acompañado de los textos que dieron sostén a la presente investigación, nos permite ver una concepción de poder en tanto producción positiva de un cuerpo. El poder del soberano sobre la vida, plantea Foucault (2002; 164), es el derecho de hacer morir o dejar vivir. El poder que se genera, en cambio, en el XVIII, es un poder positivo que administra la vida, la controla y la aumenta, que se ejerce en el nivel de la vida y asume la función de administrar y gerenciar la vida misma. Es en el potencial de la vida donde el poder se despliega. Se entiende así la racionalidad del poder, estas tácticas intencionales con miras y objetivos precisos, que se encadenan y propagan armando dispositivos de poder desde estos múltiples focos que se analizan en el trabajo construyendo un complejo entramado que atraviesa y excede a las mismas instituciones.

La introducción del término ortopedia, la importancia de haber sido nombrada, no implica en sí el inicio de la historia de la ortopedia misma. Pero sin lugar a dudas, la introducción de la palabra implica una nueva forma de experiencia, el crecimiento de nuevos conocimientos, el establecimiento de nuevas normas pedagógicas, médicas y familiares en un cambio en el modo en que los individuos dan sentido y materialidad a sus cuerpos. Si la ortopedia infantil mereció ser nombrada como tal, especificada y separada de otros ámbitos vecinos y recibe de allí en más el desempeño y la explotación de su saber y conocimiento, es gracias a las relaciones de poder, las técnicas de saber y los procedimientos discursivos que la instituyen y delimitan en tanto objeto pasible de ser sitiado. Constituido como tal a partir de pequeñas bases, como la vigilancia del cuerpo infantil en el SXVIII, que se encadenan entre sí. La 
distribución y apropiación de poder y saber se inscriben en tanto corte en cierto recorrido, que en este caso particular implica el crecimiento de una nueva matriz y atraviesa permanentemente alteraciones y desplazamientos en su recorrido. Este mecanismo científico disciplinario implica un mayor conocimiento que conlleva a una mayor sujeción y no al concepto tradicional de la ilustración que plantea un mayor saber para la obtención de una mayor libertad.

Los textos abordados se ocupan del saber, concebido en su vinculación al poder, que opera y operó permanentemente sobre el cuerpo, y de cómo operan en nosotros esas creencias. Esta investigación en el recorrido de las pedagogías de la postura se centra en el ajuste de la arquitectura corporal, de la anatomía del cuerpo que recorre estéticas y políticas que mantienen el interés por la rectitud corporal, el abordaje de las pedagogías en tanto portadoras de preceptos que dan al cuerpo una forma y lo cuadriculan para someterlo a normas con mayor seguridad aún de lo que haría el pensamiento (Vigarello; 2005). La cuestión fundamental es, entonces, el gobierno de la vida misma; y la retroalimentación entre la modelación del cuerpo y la producción de saberes sobre esos cuerpos modelados. Hacemos referencia a un poder que se hizo cargo del cuerpo y de la vida, que tomó a su cargo la vida en general con el polo del cuerpo y el polo de la población. Ante todo es evidente la solidaridad de los modelos con la ciencia, así como también con las técnicas, con políticas de Estados que buscan fortalecer a sus individuos y buscan el progreso de una generación, incluyendo la evaluación de la rentabilidad; una pedagogía que corrige cuerpos y se entreteje en una encrucijada en la cual convergen múltiples elementos.

Realizar esta lectura en el marco del orden del poder político nos permite entonces observar la implantación y expansión de la ortopedia infantil, con su teoría médica científicamente insuficiente y excesivamente moral ${ }^{22}$.

La observación y reglamentación de la anormalidad del cuerpo del niño mide su cuerpo y penetra en la conducta. Estas correcciones sobre el cuerpo infantil, intensificadas, diferenciadas y aisladas, son incorporadas a la vida de cada día. La multiplicación y expansión de discursos circulan en dirección a que cada familia y cada individuo sea capaz de controlar aquello que el estado requiere: cuerpos fuertes.

\footnotetext{
${ }^{22}$ Pero por "moral” entendemos también el comportamiento real de los individuos, en su relación con las reglas y valores que se les proponen: designamos así la forma en que se someten más o menos completamente a un principio de conducta, en que obedecen una prohibición o prescripción o se resisten a ella, en que respetan o dejan de lado un conjunto de valores(...) (Foucault; 2003; 26).
} 
Se construye una producción de discursos y un interés en la población sobre el cuerpo, susceptible de funcionar y de establecer una economía sobre él. Al mismo tiempo que se elabora un ideal de rentabilidad y recursos del cuerpo, señalando una postura que manifiesta una capacidad rigurosamente trabajada, se elabora una profundización de las referencias que establecen las normas anatómicas de la corrección del cuerpo, una organización de la mecánica del cuerpo que conlleva a su vez el bienestar del espíritu.

El triunfo del cuidado del cuerpo infantil se constituye en esta alianza provechosa de un médico que pauta y una madre que, controlando, ejecuta. Una doctrina médica congruente con una moral educativa. La población y los cuerpos individuales pasan a ser una cuestión pública, pasan a ser el objetivo de las estrategias políticas: el cuerpo comienza a ser organizadamente introducido en los engranajes de producción.

Se reglamentan principios que mecanizan el trabajo de los cuerpos; al tiempo que se gobierna el funcionamiento del cuerpo, se gobierna el enfoque de quienes lo educan. Se materializan modos de conformación de un cuerpo y aumenta la atención que reciben la rectitud y el porte: se uniforman cuerpos bajo el lema de un cuerpo infantil libre y natural, se trata de establecer una liberación física y una protección moral tanto en la educación pública como privada.

El siglo XVIII insiste en la maleabilidad, la flaqueza y la debilidad del cuerpo infantil y en el juicio escaso y desorganizado que poseen los niños, lo cual justifica en una primer instancia una tutela más estricta por parte de ciertos adultos: los padres; hacia quienes está dirigido principalmente el texto de Andry, en su intento novedoso de consolidar una pedagogía estricta y específica de la postura infantil. Su preocupación por la corrección del cuerpo se centra en la infancia para lograr un buen hombre hecho; para hacer de los niños niños bellos y de proporciones perfectas. La degeneración es la gran preocupación y viene a insertarse en tanto pieza teórica fundamental de la medicalización del anormal. Foucault describe tres transformaciones: el pasaje a la somatización, el problema de la carne que tiende a convertirse en el problema del cuerpo; la infantilización, en tanto organización centrada en torno al autoerotismo infantil y la medicalización que hace referencia a un modo de control que se apoya en el saber y el poder médico. La familia se constituye así en una célula de protección, guía y normalización del cuerpo infantil. La familia es el núcleo disciplinador. Funciona como engranaje de disciplinas. 
La medicina -con su mira en la sexualidad y la fisiología de la procreación de las mujeres-, la pedagogía centrada en el niño y la economía puntualizada en las mediciones demográficas van forjando un uso de la sexualidad que pasa a ser asunto del Estado en el cual tanto la población como cada uno de sus individuos son instados a controlarse. A partir del siglo XVIII el sexo de los niños y las construcciones que a partir de ello se entretejen pasan entonces a ser un tema de Estado: se disponen a su alrededor estrategias discursivas y dispositivos institucionales. El dispositivo de sexualidad intensifica, durante el siglo que nos ocupa, la proximidad afectiva y corporal de padres a hijos. Estas observaciones del cuerpo infantil y sus efectos sobre la población se inscriben pues, en el límite entre lo biológico y lo económico, bajo los modos de norma médica. Lo particular del la ortopedia infantil en el siglo XVIII, además de su nombramiento, es el inicio de una autonomía, la eficacia en el orden del poder y una creciente productividad en el terreno del saber. A partir de los aportes de Andry, surge con mayor precisión la intención y planificación de vigilar y corregir el porte: el cuerpo débil infantil es la principal causa de la deformidad, es el niño en quien hay que poner la mirada. Un niño ideal, que parece encarnarse en el niño normal, sobre el cual se intenta imponer reglas cada vez más meticulosas de observación y corrección en una dirección precisa y ajustada.

La historia de la pedagogía correctora da cuenta también del interés por un cuerpo capaz de desarrollar aptitudes y nuevas motricidades. Destaca en el caso particular de la segunda mitad del siglo XVIII una nueva mirada sobre la población: la intensa atención sobre el lactante, la revalorización de la maternidad y el pecho, el alerta sobre el fajado y uso del corsé, el inminente peligro de la urbanidad y la degeneración del cuerpo que amenaza su rectitud. La preocupación por la degradación de la población crece en paralelo a la posibilidad de corrección. El ideal de cuerpo sujetado y refinado de los salones de la aristocracia comienza a virar hacia la formación de un cuerpo más dinámico y rudo en algunas de sus formas y proporciones. El corsé es incluido también en la lista de factores de debilitamiento del cuerpo. El código clásico de actitudes, ademanes y posturas queda adherido a la señal de debilitamiento. El cuerpo deseado ya no es aquel que enfunda sus pertenencias, sino el que a través de la higiene y el ejercicio logra una forma que implica vigor y rectitud, un cuerpo que se pueda sostener. Un nuevo orden de la fuerza y dinamismo del cuerpo que elabora principios de trabajo del individuo. 
La postura es concebida en términos de voluntad: se debe guiar al niño para que mantenga con esfuerzo la rectitud. Un cuerpo responsable de su propio poder corrector que explota sus propias fuerzas. La solución del corsé que comprime vira hacia el ejercicio que ordena bajo un esfuerzo compensador, aunque queda atrapada aún por una simple visión intuitiva de los modos de corrección. La corrección, rescata Andry, debe venir de adentro. La rectitud deseada, hasta entonces circunscripta al corsé, entrama ahora una nueva forma que enlaza al niño en su sistema de exigencia y racionalización que sostiene la vigilancia al tiempo que aumenta la eficacia. Se racionalizan las posiciones e interiorizan los controles: es el esfuerzo del sujeto. Se delega la fuerza correctiva en el niño al tiempo que la mano del adulto -en esta modalidad en apariencia más sutil y alejada- moldea la forma correcta. Vigarello $(2005 ; 27)$ subraya que de esta renovación, el texto de Andry no es más que un comienzo, tan decisivo como discreto y limitado.

Se trata de una enseñanza de las posturas en la que lo que subyace es la referencia a la regla métrica, el ejercicio preciso de ciertas fuerzas para que se uniformen los cuerpos. El ideal que avala el modo de poner en práctica tales estrategias se enmarca directamente en el niño normal. Con Andry aparecen ejercicios que llevan a una actitud correcta. Se plantea una corrección voluntaria que empuja la rectitud hacia una perfección mantenida, se instaura el esfuerzo por superar las simples exigencias comunes y guiar al niño a través de puntos de referencia indicativos (Vigarello; 2005, 23). También la ropa (así como el trabajo silencioso de costureras y modistas) revela la imposición detallada de un corte y un porte que con severidad se impone en la burguesía: pecho saliente y vientre contraído. Las iconografías y las revistas de modas difunden también la postura indicada. Andry propone ejercicios que por primera vez conciernen exclusivamente a la rectitud tan deseada y anhelada. Su discurso es resaltado por Vigarello como expositor de una nueva ponencia que como tal implica un discurso que pertenece a dos mundos: está repartido entre la visión de un cuerpo sometido al masaje modificador y la que lo abre a una mayor autonomía. "El niño se encuentra encerrado en una fijación activa" (Vigarello, 2005; 85). En apariencia se podría pensar que el corsé ha derivado en formas más móviles, sin embargo la sujeción sigue estando presente aún en los espacios más cotidianos; y será justificada -haciendo referencia al campo científico- como una necesidad de regeneración que, al mismo tiempo y por su intermedio, prepara y fortalece organizaciones, cuadricula y define espacios. 
La ambición de un cuerpo recto no es abandonada, pero sí cambian sus métodos y sus justificaciones. La causa social de la buena forma resulta renovada por una exigencia higiénica y fisiológica. Lo que resulta evidente del estudio de las pedagogías de la corrección del cuerpo es la puesta en marcha de modelos que regulan la arquitectura física, su perfectibilidad y sus recursos (Vigarello; 2005; 240).

La complejidad de la problemática de la corrección del cuerpo no se limita al cumplimiento por parte de la población de las órdenes que ejecuta el Estado o la medicina. Pensar en el cuerpo inmerso en el campo político es pensar las relaciones de poder que actúan sobre él de manera inmediata. El cuerpo sujetado, sostenido en estas relaciones de poder, es un cuerpo sometido y es a su vez un cuerpo productivo. La especificidad del cuerpo sometido puede pertenecer a una modalidad sutil pero a su vez medida, organizada y reflexiva que de todos modos se inscribe en el aspecto físico. Existe un saber del cuerpo que incluye y excede el área científica que constituye lo que Foucault $(1989$; 33) llama tecnología política del cuerpo, constituida de modo difuso, localizada de manera indefinida pero que sin embargo denota una gran coherencia en su resultado y eficacia. Por lo tanto, los ámbitos transitados en nuestra investigación -la estética, la medicina, la familia, etc.- no son en sí la única localización posible y certera de la instauración de la pedagogía correctora del cuerpo, sino que nos permiten dar cuenta de algunos de los procedimientos que fortalecen esa dirección. Es una microfísica del poder de las cuales las instituciones toman elementos, ejercen juicios de valor, utilizan e imponen parte de sus procedimientos; pero su campo de validez se sitúa justamente entre esos funcionamientos y en la materialidad misma de sus cuerpos y sus fuerzas.

Este nuevo cuerpo sometido a movimientos es concebido en tanto cuerpo natural, susceptible de modificar sus elementos constitutivos, y capaz de organizar y explotar su propia fuerza. Estas nuevas técnicas de sujeción centran sobre el cuerpo su campo de acción atrapándolo en nuevos mecanismos de poder y ofreciéndolo a nuevas formas de saber. La conformación de la pedagogía del cuerpo responde a una nueva red de justificaciones que la avalan y expanden en múltiples direcciones: se explicitan los modos de corregir el cuerpo en un tiempo y un espacio, se trata de lograr una disposición del tiempo que genere cada vez mayor utilidad del cuerpo en cuestión.

La práctica misma de la enseñanza da cuenta de la regulación de la corrección y de su vigilancia no como un elemento más sino como una pieza fundamental en pos de una mayor eficacia, un control que se multiplica de manera anónima y automática. El 
ejercicio es una técnica que propone repeticiones y diferenciaciones siempre organizados en un tiempo que controle la dominación del movimiento en una organización progresiva. El ejercicio tiende a una sujeción. Se organiza al cuerpo del individuo en tanto segmento de una maquinaria mayor de la cual es parte: la población.

El texto de Andry prescribe, ordena, bosqueja en el sentido que traza de antemano un plan que reproduce los trazados sobre el cuerpo con modalidades que despliegan la obligación y la prohibición, lo permitido y lo que no es tolerado. Despojado de cualquier amplificación técnico-científica, su testimonio tampoco logra crear obra en el sentido de las artes: es una apuesta a la escritura que se adentra de modo expreso en el interior de la familia. Los padres son llamados a tallar en el cuerpo, sobre un cuerpo niño que no sabe nada y que aprenderá el orden sobre su cuerpo. El sacrificio del cuerpo mantiene el lugar del orden. El trabajo sobre el cuerpo infantil adquiere una impresión corporal estética. El desorden extremo del cuerpo es la muerte y su orden da forma a un cuerpo que se inserta en un ámbito productor. Esta consolidación del cuerpo infantil capturada y retocada por el mandato de la rectitud, del cuerpo vigoroso que denota salud, da cuenta de la constitución de los individuos como elementos correlativos de un poder y un saber, en el marco de un ejercicio del poder que pasa a ser controlable por la sociedad misma.

Esta ironía de la liberación del cuerpo expuesta por Andry se propone trabajar sobre una infancia que debe ser conducida, que da cuenta de que ya es pero sin ser algo aún. Si la infancia es la expansión de la inquietud, se trata justamente de dar y ajustar sentido, de superar con apuro la indefinición, en este caso, de un cuerpo susceptible de ser deforme.

Permitirse desacralizar ciertos modelos e interrogarse acerca de la técnica misma de cada observación, nos invita a re-pensar estos cuerpos ideales desde la pedagogía de la corrección, como portadores no de una única, sino de múltiples y permanentemente variadas significaciones. La intención se ha centrado en investigar las formas de racionalidad que organizan cierto modo de obrar, esto es, la manera en que se hace, el acto mismo y la libertad de los individuos dentro de ese sistema práctico: desde el corsé del siglo XVI hasta la mano que modifica el cuerpo del niño hacia la interiorización de las normas, se busca otorgar una creciente autonomía al cuerpo del niño. Los cuerpos parecieran verse cada vez más manipulados de un modo más preciso y menos tangible en cada nueva organización de esta anatomía 
política del cuerpo. El cuerpo, propiedad del rey en el antiguo régimen, lugar donde el soberano ejerce sus marcas, es ahora objeto de una apropiación colectiva y útil.

La corrección del cuerpo ha sido pensada aquí en su orientación hacia una pedagogía del cuerpo, en términos de continuidades y rupturas: la continuidad por la preocupación de la morfología del cuerpo, en particular por la construcción de una línea recta en tanto referencia continua y las incesantes modificaciones en las discursividades y prácticas que plantea un discurso pedagógico de las que parecieran emerger nuevas formas de cuerpos, detallados, esculpidos, con referencias sumamente minuciosas. Esto forma parte del pensar el modo en que somos constituidos como sujetos de nuestro saber, en relación a un poder y en tanto sujetos morales de nuestras acciones.

La corrección del cuerpo no es una idea abstracta, un imaginario. Tampoco es simplemente la construcción biológica de una postura músculo-esquelética, sino que implica, como se ha intentado recorrer en el presente trabajo, una concepción del funcionamiento del cuerpo, un modo educativo, una actitud valorativa particular que adopta diferentes tácticas en cada recorte posible de la historia. No sólo es la metáfora del cuerpo la que vira sino también sus mediciones, sus referencias, los objetos tangibles que encierran o liberan el torso. Entrar en la historia de la corrección del cuerpo, en el estudio de la diferenciación de los modelos que dan una textura a los mismos, permite leer las condiciones de posibilidad y los recorridos de los diversos dispositivos que se anudan para asegurar la rectitud de las anatomías.

Quedan al menos dos grupos de preguntas por plantear. El primero, referido a si hubiera sido posible otro modo de organizar, pensar, constituir la corrección del cuerpo infantil en el contexto histórico-político en el que Andry edita su libro. El segundo grupo gira en torno a la continuidad-discontinuidad, a los modos de transformación y/o transferencia del modo de relacionarse de los individuos con la corrección, forma y postura del cuerpo en nuestros días. 


\section{Bibliografía}

Agamben, Giorgio, Lo abierto. El hombre y el animal, Pretextos, Valencia, 2005. , Infancia e historia, Adriana Hidalgo Editora, Buenos Aires, 2003.

Andry de Boisregard, N., L'orthopédie ou l'art de prévenir et de corriger dans les enfants les difformites du corps, Bruselas,1743.

Badinter, Elisabeth, Existe el instinto maternal? Historia del amor maternal. Siglos XVII al XX, Paidós, Barcelona, 1991.

Badiou, Alain, "Panorama de la filosofía francesa contemporánea", Eikasia, Revista de filosofia, Oviedo, mayo 2006.

Ballesteros Massó, R.; Gómez Barrena, E.; Delgado Martínez, A.D. (Grupo de Investigación - CTS-380: Cirugia Ortopédica), "Siglo XVII - Nicolás Andry" :

www.ujaen.es/investiga/cts380/historia/siglos xvii.htm n "Historia de la Traumatología y Cirugía Ortopédica" (http://www.ujaen.es/investiga/cts380/historia/ ), Julio 2002, Universidad de Jaén. (www.ujaen.es )

Benjamín, Walter, Infancia en Berlín hacia 1900, Alfaguara, Buenos Aires,1990. , Conceptos de filosofía de la historia, Derramar Ediciones, La Plata, 2007.

Berlin, Isaiah, Las raíces del romanticismo, Taurus, Madrid, 2000

Castro, Edgardo, El vocabulario de Michel Foucault. Un recorrido alfabético por sus temas, conceptos y autores, Prometeo 3010/ Universidad Nacional de Quilmes, Bernal, 2004. 
,Michel Foucault: La analítica del poder (Lectura y análisis de los cursos: "Hay que defender la sociedad" y Los anormales), sin fecha, mimeo.

Danto, Arthur, El abuso de la belleza. La estética y el concepto del arte, Paidós, Barcelona, 1999.

, Después del fin del arte. El arte contemporáneo y el linde de la historia, (Cap 1) Paidós, Buenos Aires, 2007.

Donzelot, Jacques, La policía de las familias, Pretextos, Valencia, 1998.

Forster, Ricardo, "Las políticas del cuerpo" en Crítica y sospecha. Los claroscuros de la cultura moderna, Paidós, Buenos Aires, 2003.

Foucault, Michel, Vigilar y castigar. Nacimiento de la prisión, Siglo XXI, Buenos Aires, 1989.

, ¿Qué es la ilustración?, La Piqueta, Madrid, 1996.

, La vida de los hombres infames, Altamira, La Plata, 1996.

, Defender la sociedad, Fondo de Cultura Económica, Buenos

Aires, 2000.

,Historia de la sexualidad I, La voluntad del saber, Siglo XXI, Buenos Aires, 2002.

, Historia de la sexualidad 2, El uso de los placeres. Siglo XXI, Buenos Aires, 2003.

, Historia de la sexualidad 3, La inquietud de sí, Siglo XXI, Buenos

Aires, 2003. 
Hauser, Arnold, Historia social de la literatura y el arte, Guadarrama, Madrid, 1974.

Kohan, Walter, Infancia entre educación y filosofía, Alertes, Barcelona, 2004.

, Infancia, política y pensamiento. Ensayos de filosofía y educación,

Del Estante Editorial, Buenos Aires, 2007.

Lyotard, J.F., Lecturas de infancia, Eudeba, Buenos Aires, 1997.

Nari, Marcela. Políticas de maternidad y maternalismo político, Biblos, Buenos Aires, 2004.

Vigarello, George, Historia de la belleza. El cuerpo y el arte de embellecer desde el Renacimiento hasta nuestros días, Nueva Visión, Buenos Aires, 2004.

, Corregir el cuerpo. Historia de un poder pedagógico, Nueva Visión,

Buenos Aires, 2005.

Yalom, Marilyn. Historia del pecho, Editorial Los 5 sentidos, Barcelona, 1997.

AAVV, "The grandfather of orthopaedics", papper The Association of Bone and Joint Surgeons, in conjunction with Clinical Orthopaedics and Related Research

(http://www.diavlos.gr/orto96/ortowww/andry1.htm) 


\section{Índice de llustraciones}

Imagen del árbol con el tutor (Andry, LIII; 253) ..............................

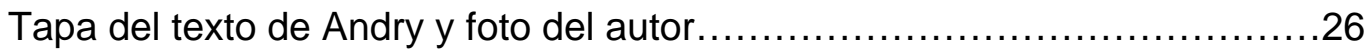

Imagen del árbol con el tutor re-utilizada en instituciones pertenecientes al ámbito de la ortopedia en la actualidad. (Orthopedic (Andry) Iconography, Clinical Orthopedics and related Research, nro 200, noviembre 1985)........27

Modos de mejorar las sillas de paja para facilitar una adecuada postura de los

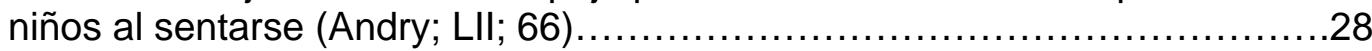

Ejercicios para reforzar la belleza del talle y la cuadratura de las clavículas (Andry, LII; 60).

Mano del adulto en su intervención para la corrección de las deformidades de la cabeza en el niño. (Andry; LII; 86)

Las relaciones adecuadas de las partes del cuerpo y su basamento en las ciencias de la mecánica (Andry; L!; 37).

Cuidados que debe tener una nodriza con la cabeza del niño (Andry; LII; 99)

Linneo, Fauna suecica (1746). Imagen reproducida en el escrito de Linneo, donde refleja la preocupación de la época por los pechos de la mujer. (Yalom; 1997,136)

Auguste Claude Le Grand, Jean Jacques Rousseau ou l'Homme de la Nature. Grabado 1785. La obra incluye un grabado que afirma: El restituyó a las mujeres sus obligaciones y a los niños la felicidad. (Yalom; 1997; 38).... 
Cuencos de porcelana de la granja de Rambouillet, fabricados en Sévres para maría Antonieta. La leyenda cuenta que se han fabricado con el molde del pecho de maría Antonieta. (Yalom; 1997; 140)...........................................70

La France Republicane, ouvrant son sein á tous ses citoyens, 1790. Imagen de la Nueva República francesa representada con frecuencia como una mujer que abre su pecho a todos sus ciudadanos. (Yalom; 1997; 145)....................71 